\title{
The VGF-derived Peptide TLQP21 Impairs Purinergic Control of Chemotaxis and Phagocytosis in Mouse Microglia
}

\author{
Nirmeen Elmadany, ${ }^{1,2 \star}$ Felipe de Almeida Sassi, ${ }^{1 \star}$ Stefan Wendt, ${ }^{1}$ Francesca Logiacco, ${ }^{1}$ Josien Visser, ${ }^{1}$ Verena Haage, ${ }^{1}$ \\ Daniel Perez Hernandez, ${ }^{3}$ Philipp Mertins, ${ }^{3}$ Dolores Hambardzumyan, ${ }^{4}$ Susanne Wolf, ${ }^{1}$ Helmut Kettenmann, ${ }^{\dagger}$ \\ and Marcus Semtner ${ }^{\dagger}$ \\ ${ }^{1}$ Cellular Neurosciences, Max-Delbrück-Center for Molecular Medicine in the Helmholtz Association, 13125 Berlin, Germany, ${ }^{2}$ Department of Biology, \\ Chemistry, and Pharmacy, Institute of Pharmacy, Freie Universität Berlin, 12169, Berlin, Germany, ${ }^{3}$ Proteomics Platform, Max-Delbrück-Center for \\ Molecular Medicine in the Helmholtz Association and Berlin Institute of Health, 13125 Berlin, Germany, and ${ }^{4}$ Department of Oncological Sciences, The \\ Tisch Cancer Institute and Department of Neurosurgery, Mount Sinai Icahn School of Medicine, New York, New York 10029
}

Microglial cells are considered as sensors of brain pathology by detecting any sign of brain lesions, infections, or dysfunction and can influence the onset and progression of neurological diseases. They are capable of sensing their neuronal environment via many different signaling molecules, such as neurotransmitters, neurohormones and neuropeptides. The neuropeptide VGF has been associated with many metabolic and neurological disorders. TLQP21 is a VGF-derived peptide and has been shown to signal via C3aR1 and C1qBP receptors. The effect of TLQP21 on microglial functions in health or disease is not known. Studying microglial cells in acute brain slices, we found that TLQP21 impaired metabotropic purinergic signaling. Specifically, it attenuated the ATP-induced activation of a $\mathrm{K}^{+}$ conductance, the UDP-stimulated phagocytic activity, and the ATP-dependent laser lesion-induced process outgrowth. These impairments were reversed by blocking $\mathrm{C} 1 \mathrm{qBP}$, but not $\mathrm{C} 3 \mathrm{aR} 1$ receptors. While microglia in brain slices from male mice lack C3aR1 receptors, both receptors are expressed in primary cultured microglia. In addition to the negative impact on purinergic signaling, we found stimulating effects of TLQP21 in cultured microglia, which were mediated by C3aR1 receptors: it directly evoked membrane currents, stimulated basal phagocytic activity, evoked intracellular $\mathrm{Ca}^{2+}$ transient elevations, and served as a chemotactic signal. We conclude that TLQP21 has differential effects on microglia depending on C3aR1 activation or C1qBP-dependent attenuation of purinergic signaling. Thus, TLQP21 can modulate the functional phenotype of microglia, which may have an impact on their function in health and disease.

Key words: C1qBP; C3aR1; microglia; purinergic signaling; TLQP21; VGF

Significance Statement

The neuropeptide VGF and its peptides have been associated with many metabolic and neurological disorders. TLQP21 is a VGF-derived peptide that activates $\mathrm{ClqBP}$ receptors, which are expressed by microglia. We show here, for the first time, that TLQP21 impairs P2Y-mediated purinergic signaling and related functions. These include modulation of phagocytic activity and responses to injury. As purinergic signaling is central for microglial actions in the brain, this TLQP21-mediated mechanism might regulate microglial activity in health and disease. We furthermore show that, in addition to C1qBP, functional C3aR1 responses contribute to TLQP21 action on microglia. However, C3aR1 responses were only present in primary cultures but not in situ, suggesting that the expression of these receptors might vary between different microglial activation states.

\section{Introduction}

Microglial cells are involved in essentially all brain diseases, including neurodegenerative disorders, traumatic brain injury, and

Received June 21, 2019; revised Dec. 20, 2019; accepted Jan. 23, 2020.

Author contributions: N.E., F.d.A.S., S. Wendt, D.H., S. Wolf, H.K., and M.S. designed research; N.E., F.d.A.S., S. Wendt, F.L., J.V., V.H., P.M., D.P.H., and M.S. performed research; N.E., F.d.A.S., and M.S. contributed unpublished reagents/analytic tools; N.E., F.d.A.S., S. Wendt, and M.S. analyzed data; N.E., F.d.A.S., S. Wendt, D.H., H.K., and M.S. edited the paper; N.E. and M.S. wrote the paper.

This work was supported by Deutsche Forschungsgemeinschaft SFB TRR43, EXC 257 NeuroCure, HelmholtzGemeinschaft, Zukunftsthema Immunology and Inflammation ZT-0027, and Einstein-Stiftung. N.E. was supported by a Deutscher Akademischer Austauschdienst scholarship. We thank the Advanced Light Microscopy facility of the Max-Delbrück-Center Berlin-Buch for technical assistance with confocal microscopy and Imaris-based data analysis. psychiatric diseases (Wolf et al., 2017). They constantly scan the environment and rapidly respond to brain injury (Davalos et al.,

\footnotetext{
The authors declare no competing financial interests.

${ }^{*}$ N.E. and F.d.A.S. contributed equally to this work as first authors.

${ }^{\dagger}$ H.K. and M.S. contributed equally to this work as last authors.

Correspondence should be addressed to Marcus Semtner at marcus.semtner@mdc-berlin.de.

S. Wendt's present address: Djavad Mowafaghian Centre for Brain Health, University of British Columbia, Vancouver, British Columbia V6T 1Z3, Canada.

J. Visser's present address: Neuroglial Interactions in Cerebral Physiopathology, Center for Interdisciplinary Research in Biology, Collège de France, CNRS UMR 7241, INSERM U1050, Labex Memolife, PSL Research University, Paris, France.

S. Wolf's present address: Department of Ophthalmology, Charité, 13353 Berlin, Germany.
} 
2005; Nimmerjahn et al., 2005). They are the professional phagocytes of the brain that remove dead cells and debris and therefore play an important role in brain homeostasis. Here we analyzed the role of a signaling peptide and its role in modulating microglial functions. VGF (nonacronymic) is a neuropeptide precursor that is widely expressed throughout the brain and is involved in many developmental and homeostatic processes, including neuronal differentiation, synaptic plasticity, and memory formation (Alder et al., 2003; Sato et al., 2012; Lin et al., 2015; Sakamoto et al., 2015). VGF is mainly expressed by neurons (Zhang et al., 2014) where it is hydrolyzed by prohormone convertase I and II enzymes into peptides before being secreted. VGF and its peptides are reported to be involved in many brain diseases, such as major depression disorder, amyotrophic lateral sclerosis, frontotemporal dementia, Parkinson's disease, and cancer (Lewis et al., 2015; Jiang et al., 2019; Llano et al., 2019; van Steenoven et al., 2019; Cocco et al., 2020). Several studies suggest VGF peptides as a potential biomarker, as CSF concentrations are often altered upon the onset and progression of brain diseases. Thus, in Alzheimer's disease (AD), VGF-derived peptides are significantly decreased in the CSF of AD patients (Carrette et al., 2003; Hendrickson et al., 2015; Spellman et al., 2015).

The C-terminal peptide of VGF, TLQP21, gained remarkable attention in the last years, being studied in contexts, such as neural cell survival (Severini et al., 2008), energy balance (Bartolomucci et al., 2006), lipolysis (Possenti et al., 2012), reproduction (Pinilla et al., 2011; Aguilar et al., 2013), blood pressure (Fargali et al., 2014), digestion (Severini et al., 2009), and pain (Rizzi et al., 2008; Chen et al., 2013; Fairbanks et al., 2014). Despite being studied in different neuroendocrine cell types, the role of TLQP21 in brain immunity exerted by microglia cells is still not known. Microglia express receptors, which are potentially activated by TLQP21, namely, C1qBP and C3aR1. TLQP21 has indeed been previously described as a ligand for these receptors indicating an involvement of this peptide in immunoregulation (Chen et al., 2013; Hannedouche et al., 2013). C3aR1 is a G-protein-coupled receptor expressed on cells of myeloid origin, including microglia, but also other cell types. VGF is involved in many biological processes, including neurogenesis and hormone release, insulin resistance, macrophage infiltration, and homing of hematopoietic progenitor cells to bone marrow (Klos et al., 2013). C1qBP is the first subcomponent of the classical pathway for complement activation, and it has been shown to bind to many different ligands involved in immune surveillance. The receptor is ubiquitously expressed and is present in various compartments of the cell. It also plays a role in different pathologies, including infection and carcinogenesis (Peerschke and Ghebrehiwet, 2007), which can be altered upon disease.

Here we studied the effects of TLQP21 on microglia and found that this VGF-derived peptide evoked intracellular $\mathrm{Ca}^{2+}$ elevations and outwardly rectifying membrane currents in microglia in a C3aR1-dependent fashion. Notably, we found that TLQP21 downregulates subsequent ATP and UDP-mediated purinergic membrane responses in a C1qBP-dependent manner. Many of the microglial features, such as phagocytic activity and directed process motility, are regulated by purinergic signaling (Haynes et al., 2006; Koizumi et al., 2007; Dissing-Olesen et al., 2014; Madry et al., 2018). Indeed, we found that, in acute brain slices, micro-

D.P. Hernandez's present address: Visiting Researcher, Quantitative Biology Unit, Luxembourg Institute of Health, Transversal activities, 1 A B, rue Thomas Edison, L-1445 Strassen, Luxembourg.

https://doi.org/10.1523/JNEUROSCI.1458-19.2020

Copyright $\odot 2020$ the authors glial process movement toward a laser lesion and the stimulation of phagocytosis by UDP were decreased by preincubation of the slices with TLQP21, suggesting that the VGF-derived peptide TLQP21 impairs purinergic signaling and thereby microglial functions.

\section{Materials and Methods}

We investigated the effects of TLQP21 on microglia using either brain slices from C57BL/6J or MacGreen mice (in situ) or neonatal primary cultures from P1-P3 C57BL/6J mice (in vitro).

Animals. Experiments were performed using neonatal C57BL/6J male and female mice (Charles River Laboratories) for the primary cultures. For the in situ parts, 8- to 16-week-old C57BL/6J WT or MacGreen male mice (Sasmono and Williams, 2012) were used to allow for the detection of microglial cells by their fluorescence. Animals were kept according to the German law for animal protection under a $12 \mathrm{~h} / 12 \mathrm{~h}$ dark-light cycle with food and water supply ad libitum.

Primary neonatal cultured microglia. For preparation of neonatal cultured microglia, P1-P3 male and female mice were used. After extraction of the brains, meninges and cerebellum were removed and put on ice with Hanks balanced salt solution (HBSS). The dissected brains were washed 3 times before adding trypsin $(10 \mathrm{mg} / \mathrm{ml}$, Biomol) and DNase $(0.5$ $\mathrm{mg} / \mathrm{ml}$, Worthington) in PBS. After 2-3 min of incubation, the reaction was blocked by adding DMEM containing $10 \%$ FCS. After removal of the medium, $0.2 \mathrm{mg}$ DNase was added and the cells were mechanically dissociated. This step was repeated before centrifuging the cells $10 \mathrm{~min}$ at $800 \mathrm{rpm}$ at $4^{\circ} \mathrm{C}$. The supernatant was discarded. The pellet was resuspended in DMEM (cells from 2 brains $/ \mathrm{ml}$ ) and plated (cells from 2 brains/flask) in poly-L-lysine-coated flasks. After $24-48 \mathrm{~h}$ of incubation, the cultures were washed 3 times with PBS and allowed to grow until confluent in DMEM (5 d). After this incubation period, medium was replaced by DMEM with 33\% L929 conditioned medium. After $2 \mathrm{~d}$, cells were harvested by shaking them for $30 \mathrm{~min}$ at $100-110 \mathrm{rpm}$. The supernatant was centrifuged for $10 \mathrm{~min}$ at $800 \mathrm{rpm}$ at $4^{\circ} \mathrm{C}$. The cells were counted and plated onto coverslips $\left(2.5 \times 10^{4}\right.$ cells/ coverslip $)$. This procedure was repeated twice with $2 \mathrm{~d}$ intervals.

Whole-cell patch-clamp recordings. To test whether microglial cells display TLQP21 membrane current activity, we used the whole-cell patchclamp technique on neonatal microglia in vitro. The pipette solution contained the following (in $\mathrm{mm}$ ): $130 \mathrm{NaCl}, 2 \mathrm{MgCl}_{2}, 0.5 \mathrm{CaCl}_{2}, 2 \mathrm{Na}-$ ATP, 5 EGTA, 10 HEPES, and 0.01 sulforhodamine-101 (Sigma Millipore) with an osmolarity of $280-290 \mathrm{mOsm} / \mathrm{L}$, adjusted to a $\mathrm{pH}$ of 7.3 with $\mathrm{KOH}$. Patch pipettes were pulled from borosilicate glasses and had resistances of 4-6 Mohm. Cells were plated on coverslips with a density of 4 to $5 \times 10^{5}$ cells. For the in situ experiments, acute $250 \mu \mathrm{m}$ coronal brain slices were prepared from male mice generated on a MacGreen background (Sasmono and Williams, 2012) for the identification of microglia by fluorescence on an epifluorescent microscope. The extracellular solution contained (in $\mathrm{mM}$ ): $\mathrm{NaCl}, 134 ; \mathrm{KCl}, 2.5 ; \mathrm{MgCl}_{2}, 1.3 ; \mathrm{CaCl}_{2}, 2$; $\mathrm{K}_{2} \mathrm{HPO}_{4}, 1.25 ; \mathrm{NaHCO}_{3}, 26$; D-glucose, $10 ; \mathrm{pH} 7.4 ; 310-320 \mathrm{mOsm} / \mathrm{L}$ and was gassed with carbogen $\left(95 \% \mathrm{O}_{2} / 5 \% \mathrm{CO}_{2}\right)$. Conventional patchclamp amplifiers were used (EPC9 or EPC10, HEKA). After establishing whole-cell configuration, we clamped the cell at a holding potential of $-20 \mathrm{mV}$ in voltage-clamp mode and applied a series of depolarizing and hyperpolarizing voltage steps ranging from -170 or -140 to $60 \mathrm{mV}$ for $50 \mathrm{~ms}$, each with $20 \mathrm{mV}$ increments. This protocol was repeated every $5 \mathrm{~s}$ to continuously monitor membrane currents upon substance application. The recording chamber was perfused $(4-6 \mathrm{ml} / \mathrm{min})$ with standard recording buffer, which contained the following (in $\mathrm{mM}$ ): $150 \mathrm{NaCl}, 5.4$ $\mathrm{KCl}, 2 \mathrm{CaCl}_{2}, 1 \mathrm{MgCl}_{2}, 10$ HEPES, 10 glucose, adjusted with $\mathrm{NaOH}$ to $\mathrm{pH}$ 7.4. The peptide TLQP21 ( $1 \mathrm{nM}, 10$ or $100 \mathrm{nM})$ was applied via the bath perfusion for $1 \mathrm{~min}$. The C3aR1 antagonist SB290157 (1 $\mu \mathrm{M})(\mathrm{mAB}-$ $\mathrm{ClqBP}$ ) was applied $30 \mathrm{~s}$ before, during, and $30 \mathrm{~s}$ after peptide administration. For blocking $\mathrm{ClqPB}$ receptors, primary neonatal microglia and the MacGreen slices were incubated for 40-60 min with monoclonal anti-C1qPB antibodies (anti C1qpPB $\mathrm{mAB}$ ) in a concentration of 3 $\mu \mathrm{g} / \mathrm{ml}$ (Abcam). ATP was applied 3-5 min after TLQP21 application for $1 \mathrm{~min}$. 
Calcium imaging. For calcium imaging experiments, microglial cells were seeded on glass coverslips at a density of $2.5 \times 10^{4}$ cells per coverslip and allowed to adhere to the glass for $3 \mathrm{~h}$. Cells were loaded with the calcium indicator Fluo4-AM (Thermo Fisher Scientific, F14201; $5 \mu \mathrm{M}$ in DMSO) dissolved in DMEM for $20-60 \mathrm{~min}$ at $37^{\circ} \mathrm{C}$. The coverslip was then transferred to a recording chamber on an upright epifluorescence microscope equipped with a $20 \times$ water-immersion objective (Olympus). There was a constant, local perfusion of buffer with a speed of 120 $\mu \mathrm{l} / \mathrm{min}$ through a Perfusion Pencil (AutoMate Scientific). The standard recording buffer contained the following (in $\mathrm{mM}$ ): $150 \mathrm{NaCl}, 5.4 \mathrm{KCl}, 2$ $\mathrm{CaCl}_{2}, 1 \mathrm{MgCl}_{2}, 10$ HEPES, 10 glucose, adjusted with $\mathrm{NaOH}$ to $\mathrm{pH}$ 7.4. Fluo4-AM was excited at $488 \mathrm{~nm}$ by a PolyChrome II or PolyChrome IV monochromator (Till Photonics), and pictures were taken at a frequency of $0.5 \mathrm{~Hz}$ by a Spot CCD camera (PCO). Exposure time was $100 \mathrm{~ms}$. Images were acquired by CamWare version 3.16 software (PCO). Videos were analyzed using a home-made algorithm in Igor Pro 6.3 (WaveMetrics). For analysis, cell somata were selected as ROIs, and the mean relative fluorescent intensity for each ROI and frame was determined to record the change in $\mathrm{Ca}^{2+}$ levels time for each cell. Intracellular $\mathrm{Ca}^{2+}$ elevations were counted as "responsive" when the response amplitudes exceeded three times the SD of the baseline.

FACS of microglia. The 12- to 14-week-old male C57BL/6J mice were transcardially perfused under deep anesthesia with $1 \times$ PBS. Brains were isolated, and after removal of the cerebellum and brainstem, dissociated into a single-cell suspension using Adult Brain Dissociation Kit (Miltenyi) and the gentleMACS dissociator (Miltenyi) according to the manufacturer's instructions. Subsequently, the cells were washed with PBS, passed through a $35 \mu \mathrm{m}$ nylon mesh, counted, and stained with antimouse CD11b ${ }^{+}$PE-Cyanine7 (Invitrogen; Thermo Fisher Scientific) and anti-mouse CD45 eFluor 450 (Invitrogen; Thermo Fisher Scientific) for 20 min on ice. After staining, the cells were washed once in PBS and sorted with a FACS Aria flow cytometer (BD Biosciences) according to the specified gating strategy for microglia as $\mathrm{CD} 11 \mathrm{~b}{ }^{+} \mathrm{CD} 45^{\text {low }}$ cells, washed in PBS, and the cell pellets snap frozen for storage at $-80^{\circ} \mathrm{C}$.

Protein extraction and mass spectrometry analysis. Freshly isolated microglia populations from 4 different male C57BL/6J mice or $1 \times 10^{6}$ primary neonatal culture microglia per replicate were pooled and pelleted in PBS. The samples were solubilized in Laemmli buffer and subjected to SDS-PAGE. The proteome was processed as described previously (Shevchenko et al., 2006; Kanashova et al., 2015), using an automated HTS PAL system (CTC Analytics). Peptides were extracted, purified, and stored on reversed-phase (C18) StageTips (Rappsilber et al., 2007). The eluted peptides were lyophilized and resuspended in $0.1 \%$ formic acid $/ 3 \%$ acetonitrile, then separated in a nano EasyLC 1200 (Thermo Fisher Scientific) with a $0.1 \times 200 \mathrm{~mm}$ MonoCap C18 High Resolution Ultra column (GL Sciences) at a gradient from 5\% to $95 \% \mathrm{~B}$ ( $80 \%$ acenotrile, $0.1 \%$ formic acid) and a flow rate of $300 \mathrm{nl} / \mathrm{min}$ in 360 min. The UHPLC was coupled online to an Orbitrap Q Exactive plus mass spectrometer (Thermo Fisher Scientific) for mass spectrometry analysis. The mass spectrometer was set to acquire full-scan MS spectra $(300-1700 \mathrm{~m} / \mathrm{z})$ at a resolution of 17.500 after accumulation to an automated gain control target value of $1 \times 10^{6}$ and maximum injection time of $20 \mathrm{~ms}$, and was operated in a data-dependent acquisition mode, selecting the 10 most abundant ions for MS/MS analysis, with dynamic exclusion enabled (20 s). Charge state screening was enabled, and unassigned charge states and single charged precursors excluded. Ions were isolated using a quadrupole mass filter with a $1.2 \mathrm{~m} / \mathrm{z}$ isolation window, with a maximum injection time of $60 \mathrm{~ms}$. HCD fragmentation was performed at a normalized collision energy of 26 . The recorded spectra were searched against a mouse database from Uniprot (January 2017) using the MaxQuant software package (version 1.5.2.8) (Cox and Mann, 2008) (with fixed modifications set to carbamylation of cysteines and variable modifications set to methionine oxidation). Peptide tolerance was 20 $\mathrm{ppm}$, and the minimum ratio for LFQ was set to 2 . The false discovery rate was set to $1 \%$ on protein and peptide level. Statistical analysis of the dataset was performed using $\mathrm{R}$ statistical software package (version 3.4.1), Prodigy (version 0.8.2), and Perseus software (version 1.6.0.7).

For data analysis, proteins that were only identified by site or were potential contaminants were excluded. Only those proteins discovered in at least three biological replicates were used for column-wise analysis using a two-sample $t$ test and a Benjamini-Hodgberg-based false discovery rate $<0.05$.

Agarose spot assay. The agarose spot assay was performed as described previously (Wiggins and Rappoport, 2010). Low-melting point agarose (Promega) was diluted in sterile PBS to a $0.5 \%$ agarose solution, heated, and mixed to create PBS-, TLQP21 (1, 10, or $100 \mathrm{~nm})$-, or ATP (1 mM)containing agarose spots $(10 \mu \mathrm{l})$. Two PBS control spots and two compound-containing spots were placed onto $35-\mathrm{mm}$-diameter glassbottomed cell culture dishes (MatTek), and $0.5 \times 10^{6} \mathrm{WT}$ microglia cells were added in either FCS-free DMEM medium as control or FCS-free DMEM medium containing $100 \mathrm{nM}$ TLQP21, $1 \mu \mathrm{M}$ SB290157, or 1.5 $\mu \mathrm{g} / \mathrm{ml} \mathrm{C1qpPB} \mathrm{mAB}$ and incubated for $3 \mathrm{~h}$ at $37^{\circ} \mathrm{C}$ in $5 \% \mathrm{CO}_{2}$. Subsequently, microglial cells that invaded the spots were counted and normalized to the PBS control spots.

Scratch wound-healing assay. The scratch assay was performed as described previously with adaptations (Arbibe et al., 2000; Sarkar et al., 2004). Briefly, microglial cells were seeded at a density of $5 \times 10^{4}$ cells/ dish in the glass-bottomed cell culture dish, and incubated at $37^{\circ} \mathrm{C}$ and $5 \% \mathrm{CO}_{2}$ for $24 \mathrm{~h}$. A scratch wound was created with a $10 \mu \mathrm{l}$ pipette tip on the cell monolayer, and the cells were washed with PBS. Thereafter, the cells were stimulated with TLQP21-containing medium or PBS as a control for $3 \mathrm{~h}$. Pictures were taken in premarked areas of the dish briefly after the scratch and $3 \mathrm{~h}$ thereafter. The pictures were analyzed using ImageJ, marking the initial cell-free zone and counting the cells that migrated into that area $3 \mathrm{~h}$ after treatment. The number of migrated cells was normalized to the average in control condition (100\%). A minimum of three technical replicates from three individual cultures were used to calculate the mean migratory capacity of each cell culture condition.

Boyden chamber assay. TLQP21-induced chemotaxis was tested using a 48-well microchemotaxis Boyden chamber (Neuroprobe). Upper and lower wells were separated by a polycarbonate filter $(8 \mu \mathrm{m}$ pore size; Poretics). Microglial cells $\left(2-5 \times 10^{4}\right.$ cells $)$ in $50 \mu$ l of serum-free DMEM medium were added to the upper compartment, while the lower wells contained TLQP21-containing medium or medium only. Medium with the same concentration of the peptide in the lower well was added to the upper well with cells to assess motility in the absence of peptide gradient. Culture medium was used as a control. The chamber was incubated at $37^{\circ} \mathrm{C}$ and $5 \% \mathrm{CO}_{2}$ for $3 \mathrm{~h}$. Cells remaining on the upper surface of the membrane were removed by wiping, and cells in the lower compartment were fixed in methanol for $5 \mathrm{~min}$ and subjected to Diff-Quik stain (Medion Grifols Diagnostics). The rate of microglial migration was calculated by counting cells in two fields of each well using a $10 \times$ objective. The pictures were analyzed using ImageJ via the color threshold contrast tool (selecting colors in the hue range of 150 [upper] and 240 [lower], which are specific for the migrated cells stained in red-violet). The background area from the pores was subtracted for each experiment, followed by the calculation of the area for one cell (averaged from at least 10 representative migrated cells). For each condition, 40-120 fields in 10-30 wells were analyzed using cells from at least three independent microglia preparations. The number of cells in each field were normalized to the average in control condition (100\%).

In vitro phagocytosis assay. We followed our standard protocol, which was previously described by Pannell et al. (2016). Yellow-green fluorescent Fluoresbrite carboxylated microspheres $(3 \mu \mathrm{m}$ diameter, Polysciences) were coated with FCS by shaking at $1000 \mathrm{rpm}$ for $30 \mathrm{~min}$ at room temperature. After centrifugation for $2 \mathrm{~min}$ at $900 \times g$, the supernatant was discarded and microspheres were washed and resuspended in HBSS; $4.8 \times 106$ microspheres in a solution containing either PBS only (control) or UDP $(100 \mu \mathrm{M})$ were applied on each coverslip with $5 \times 10^{4}$ seeded primary microglia for $30 \mathrm{~min}$ and incubated at $37^{\circ} \mathrm{C}$. In another set of experiments, microglia were preincubated with 100 nM TLQP21 alone or in combination with SB290157 for 30 min before the phagocytosis assay; in these experiments, TLQP21 was washed out completely before the assay started. After washing with PBS, pH 7.4, the coverslips were fixed with $4 \%$ PFA, washed and blocked in TBS containing 5\% donkey serum (EMD Millipore) and $0.1 \%$ Triton X (Carl Roth) for $1 \mathrm{~h}$. Subsequently, the cells on the coverslips were stained with anti-Ibal antibody (goat anti-Ibal, clone 5076, Abcam) in TBS containing 5\% 
A

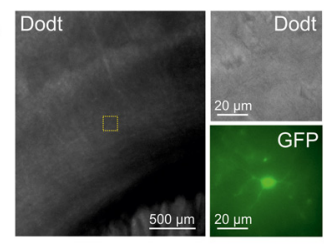

B
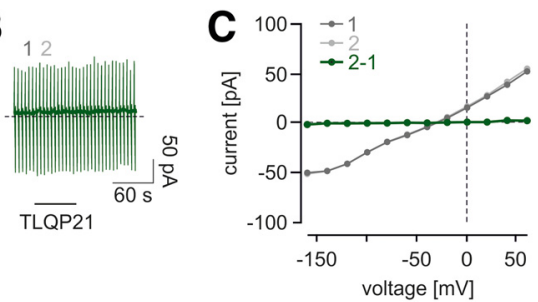

D

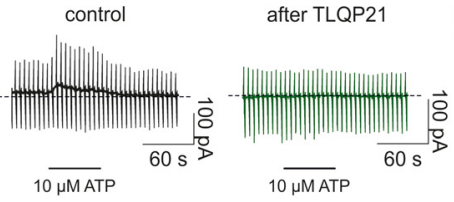

$\mathbf{E}$

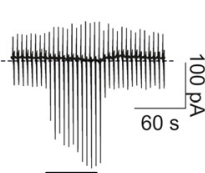

$1 \overline{\mathrm{mM} \mathrm{ATP}}$

$\mathbf{F}$

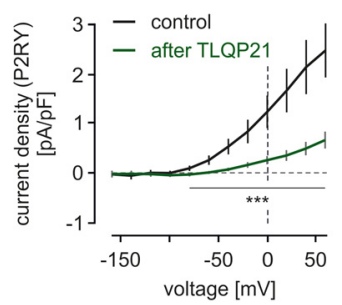

G

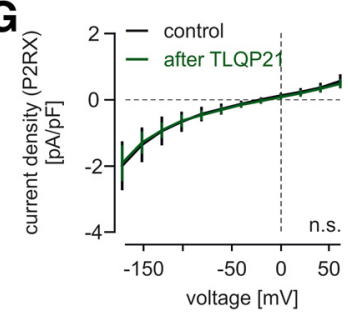

Figure 1. TLQP21 impairs microglial signaling through purinergic P2RY receptors in situ. $\boldsymbol{A}$, Transmission light and epifluorescent image of an acute brain slice from a male MacGreen mouse. Overview image represents the cortical region in which microglia were patch-clamped. A representative microglial cell is shown in higher resolution in the transmission light (Dodt gradient contrast) and in the epifluorescence ( $470 \mathrm{~nm}$ excitation) channel to show the EGFP labeling of the MacGreen mouse. $\boldsymbol{B}$, Time course of a representative patch-clamp experiment on a microglial cell. Cells were voltage-clamped at $-20 \mathrm{mV}$. A series of pulses ranging from -160 to $60 \mathrm{mV}$ were applied every $5 \mathrm{~s}$. TLQP21 (100 nM) was applied as indicated and led to no apparent changes in microglial membrane currents. C, Current-voltage relationships of the microglial recording shown in $\boldsymbol{B}$. Time points are before (1) and during (2) the application of TLQP21, as indicated in $\boldsymbol{B}$. There was no TLQP21-evoked change in membrane currents at any investigated membrane potential, as becoming visible by subtraction of the current-voltage relationships ( $2-1 ;$ green). $\boldsymbol{D}, \boldsymbol{E}$, Time courses of representative patch-clamp experiments on microglial cell. Either $10 \mu \mathrm{M}$ ATP $(\boldsymbol{D})$ or $1000 \mu \mathrm{M}$ ATP $(\boldsymbol{E})$ was applied without prior TLQP21 application (Control) or after a 1 min TLQP21 application (after TLQP21). All traces are from different recordings. Note the different appearance of the membrane responses upon 10 and $1000 \mu \mathrm{M}$ ATP, which occur due to the activation of microglial P2Y and $P 2 X$ receptors, respectively. $F, G$, Average current density to voltage relationships (CD-V) of currents induced by $10 \mu \mathrm{m}(\boldsymbol{F})$ or $1000 \mu \mathrm{M}$ (G) ATP without (black) or with (green) prior TLQP21 application. $\boldsymbol{E}$, CD-V relations are typical for metabotropic P2RY responses. $F_{,}$CD-V relations resemble the characteristics of microglial P2X currents. After TLQP21 application, there was a significant decline in the amplitudes of P2RY responses, but not of P2RX responses. ${ }^{* * *} p<0.001$. n.s., Not significant $(p>0.05)$.

donkey serum overnight. After washing, the cells were incubated with the secondary antibody (anti-goat donkey AlexaFluor-647, Dianova) and DAPI (Sigma Millipore) before mounting with Aqua-Poly/Mount (Polysciences). Four or five images per coverslip were acquired from three coverslips per condition. Phagocytosed beads per cell were quantified with an in-house-written software and Igor Pro 6.3 (WaveMetrics). Cells were grouped to $1-4,5-7,8-10$ beads per cell, and the percentage of cells in each group was multiplied by the corresponding grade of phagocytosis ( $1-4$ beads: factor $1 ; 5-7$ beads: factor $2 ; 8-10$ beads: factor 3 ). The sum of the products in each group was then defined as the phagocytosis index.

In situ phagocytosis assay. Mice were killed by cervical dislocation. Brains were removed and cooled down in ice-cold ACSF containing the following (in mM): $134 \mathrm{NaCl}, 2.5 \mathrm{KCl}, 1.3 \mathrm{MgCl}_{2}, 2 \mathrm{CaCl}_{2}, 1.25 \mathrm{~K}_{2} \mathrm{HPO}_{4}$, $26 \mathrm{NaHCO}_{3}, 10$ D-glucose, $\mathrm{pH} 7.4$, gassed with $95 \% \mathrm{O}_{2} / 5 \% \mathrm{CO}_{2}$. Brains were mounted on a vibratome (HM650V, Thermo Fisher Scientific), and $130-\mu \mathrm{m}$-thick coronal slices were generated and incubated in ACSF for $2 \mathrm{~h}$ at room temperature, which was constantly gassed with carbogen $\left(95 \% \mathrm{O}_{2} / 5 \% \mathrm{CO}_{2}\right)$. Quantification of microglial phagocytic index in acute cortical brain slices of $130 \mu \mathrm{m}$ thickness was conducted in male C57BL/6J WT mice, based on a previously published protocol (Wendt et al., 2017). A total number of 6 mice as a control, 6 mice for TLQP21treated slices, 3 mice for TLQP21 + SB290157-treated slices, and 3 mice for TLQP21 + mAB-C1qBP-treated slices were used; four slices per condition were obtained from each animal. We analyzed four randomly chosen FOVs per slice from cortical layers I-VI. Incubation with TLQP21
(100 nм), TLQP21 (100 nм) + SB290157 (1 $\mu \mathrm{M})$, or TLQP21 (100 nM) + mAB-C1qBP (3 $\mu \mathrm{g} / \mathrm{ml}$ ) was done in the second hour within the first $2 \mathrm{~h}$ after slicing. After washout of the compounds, acute brain slices were incubated with a suspension of FCS-coated Bright Blue fluorescent carboxylated microspheres $(4.5 \mu \mathrm{m}$ diameter, Polysciences). The fluorescent beads were opsonized with FCS by shaking at 1000 rpm for $30 \mathrm{~min}$ at room temperature followed by washing in PBS before adding them to the brain slices. Each brain section was incubated with $2.45 \times 10^{6}$ microspheres (in a volume of $500 \mu \mathrm{l}$ of HBSS) at $37^{\circ} \mathrm{C}$ for $1 \mathrm{~h}$ with or without $100 \mu \mathrm{M}$ UDP as indicated in Figure $7 B$. Last, sections were intensively washed with $0.1 \mathrm{M}$ PBS $(3 \times 20 \mathrm{~min})$ and subsequently fixed with $4 \%$ PFA for $1 \mathrm{~h}$ and washed with $0.1 \mathrm{M}$ PBS. Sections were incubated in a permeabilization buffer containing 2\% Triton X-100 (Carl Roth), 2\% BSA (Carl Roth), and 10\% normal donkey serum (EMD Millipore) in $0.1 \mathrm{M}$ phosphate buffer, $\mathrm{pH} 7.4$, for $4 \mathrm{~h}$, followed by the incubation with goat anti-Ibal antibody (1: 600; clone 5076 Abcam) in a dilution buffer ( $1: 10$ of permeabilization buffer in $0.1 \mathrm{M}$ PBS, $\mathrm{pH} 7.4)$ at $4^{\circ} \mathrm{C}$ overnight. Thereafter, sections were incubated with the secondary antibody donkey anti-goat AlexaFluor-647 (1:250; Dianova) for $2 \mathrm{~h}$ at room temperature. After washing, slices were mounted in Aqua-Poly/ Mount (Polysciences). Confocal laser scanning microscopy was performed on a TCS SPE using a $20 \times$ oil-immersion objective (Leica Microsystems). We acquired $21-\mu \mathrm{m}$-thick $z$ stacks at $1.05 \mu \mathrm{m}$ intervals beginning from the surface of the slice. Data analysis to assess microglial phagocytic activity was performed using Imaris 6.3.1 (Bitplane). The Iba1-positive volumes of high-resolution SPE confocal microscopy stacks were 3D surface rendered by application of threshold values of 40 and a "background subtraction" (90 $\mu \mathrm{m})$. Microspheres were detected as spots and counted automatically by the "Split into surface object" plugin. All beads having their center located within a given rendered Ibal volume were considered to be phagocytosed by microglia. The phagocytic index was calculated as followed: $n_{P M} \times 10^{4} / V_{\text {Ibal }}$ where $n_{P M}$ is the total number of phagocytosed microspheres and $\mathrm{V}_{\mathrm{Ibal}}$ is the Imaris-rendered volume of Ibal fluorescence in $\mu \mathrm{m}^{3}$.

Two-photon imaging and laser lesion. For two-photon imaging, 250 $\mu \mathrm{m}$ coronal brain slices were obtained from MacGreen male mice. The total number of slices used was $18,12,10$, and 13 slices from $8,4,5$, and 5 mice for control, TLQP21-treated, TLQP21 + SB290157, and TLQP21 + mAB-C1qBP, respectively. EGFP was excited by a Chameleon Ultra II laser (Coherent) set to $940 \mathrm{~nm}$. Images were acquired with a two-photon laser scanning microscope (Till Photonics) equipped with a waterimmersion objective (40×, NA 0.8 , Olympus). We imaged a $60-\mu \mathrm{m}-$ thick $z$ stack with a step size of $1 \mu \mathrm{m}$ covering a field of $320 \times 320 \mu \mathrm{m}$. Laser lesion was set in the cortex by focusing the laser beam, set to a wavelength of $810 \mathrm{~nm}$ and maximum power, at $20 \mu \mathrm{m}$ depth in the selected imaging volume, and scanned the tissue until autofluorescence of the injured tissue was visible. This procedure resulted in lesions with sizes $\sim 20 \mu \mathrm{m}$ in the center of the observed region. To investigate the influence of TLQP21 on the microglial response to the laser lesion, we incubated the slices before the experiment for $60 \mathrm{~min}$ in ACSF containing TLQP21 (100 nM), TLQP21 (100 nм) + SB290157 (1 $\mu \mathrm{M})$, or TLQP21 $(100 \mathrm{~nm})+$ mAB-C1qBP $(3 \mu \mathrm{g} / \mathrm{ml})$. Igor Pro 6.37 (WaveMetrics) was used for data analysis as in Davalos et al. (2005). Briefly, the sequences of 
3D image stacks were converted into sequences of $2 \mathrm{D}$ images by a maximum intensity projection algorithm. For quantification, microglial response to the focal lesion was defined as a shift of EGFP fluorescence (white pixels), associated with microglial processes, from distal into the proximal circular region, immediately surrounding the focal lesion. To eliminate signal intensity differences between different records, grayscale images were first converted into a binary form using a threshold. Proximal, lesion region was defined as the midpoint of two circles with a diameter of $45 \mu \mathrm{m}(x)$ and $240 \mu \mathrm{m}(y)$. We calculated the pixels entering the inner circle $\left(R_{x}(t)\right)$ in each frame over time subtracting the pixels of the first picture $R_{x}(0)$, thus highlighting movement of processes at the site of injury. This was then related to the pixels of the outer ring taken from the first picture directly after laser lesion $\left(R_{Y}(0)\right)$ to correct for the cell density around the lesion site. The microglial response is therefore given as $R(t)=$ $\left[R_{x}(t)-R_{x}(0)\right] / R_{y}(0)$.

Quantification and statistical analysis. Statistical analysis was performed using Igor Pro 6.37 (WaveMetrics). For all comparisons of three or more groups, one-way ANOVA followed by a Tukey post hoc test was used. Comparisons between two samples were performed using the Student's $t$ test. Column graphics display means, and error bars indicate the SEM.

\section{Results}

\section{TLQP21 impairs microglial signaling through metabotropic purinergic receptors}

To explore the effect of TLQP21 on microglia, we generated acute brain slices to record membrane currents in response to TLQP21 using the patch-clamp technique in the voltage-clamp configuration. We could identify microglia for patch-clamp experiments by using MacGreen male mice (Sasmono et al., 2003), which express EGFP in microglia (Fig. 1A). Consistent with previous data from us and other laboratories (for review, see Kettenmann et al., 2011), microglia displayed characteristic membrane currents when repetitively clamped at potentials between -170 and $60 \mathrm{mV}$ (data not shown). The application of $100 \mathrm{~nm}$ TLQP21 did not evoke microglial membrane currents (Fig. $1 B, C$ ) in 24 recordings.

As in previous studies from our laboratory (Boucsein et al., 2000, 2003; Korvers et al., 2016; Wendt et al., 2017), we applied ATP at the end of our experiment as a control for cell viability (Fig. 1D,E). Under control conditions, the application of $10 \mu \mathrm{M}$ ATP reliably evoked outwardly rectifying currents of $41.1 \pm 10.8$ $\mathrm{pA}$ at $60 \mathrm{mV}$ that reversed close to the Nernst potential for $\mathrm{K}^{+}$ $(-83.9 \pm 10.2 \mathrm{mV}, n=10$; Fig. $1 D, E)$, which were mediated by the activation of $\mathrm{P} 2 \mathrm{Y}$ receptors triggering the activation of $\mathrm{K}^{+}$ currents through THIK-1 (Butovsky et al., 2014; Ousingsawat et al., 2015; Madry et al., 2018). However, when TLQP21 was applied beforehand, the subsequent $10 \mu \mathrm{M}$ ATP application did either induce no or only small currents compared with control

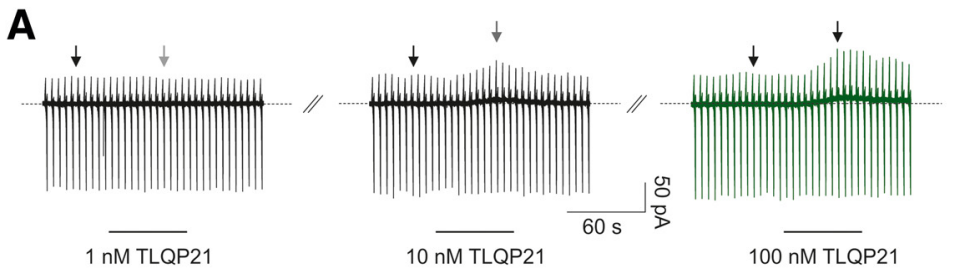

B
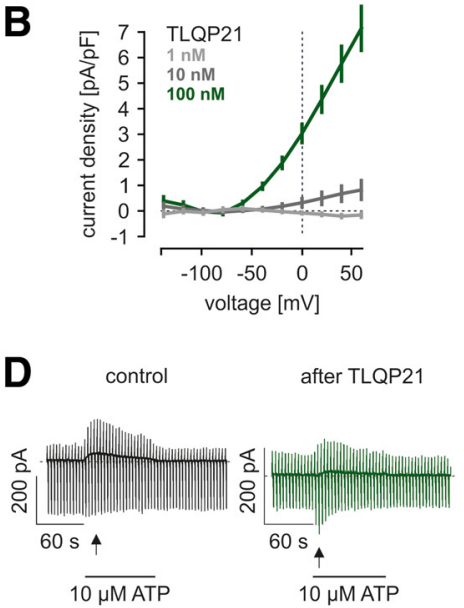

$\mathbf{F}$

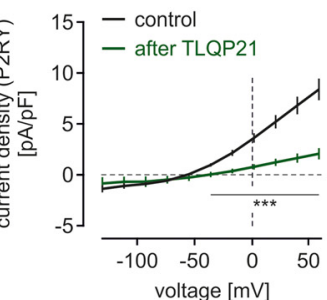

C

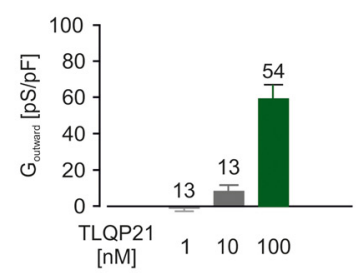

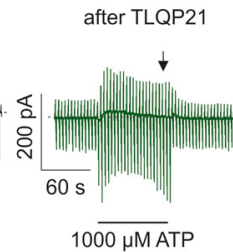

G

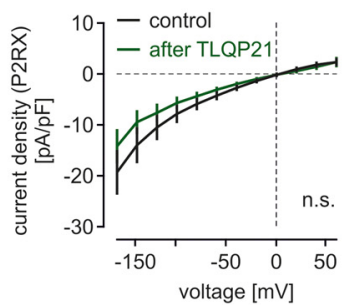

Figure 2. TLQP21 impairs microglial signaling through purinergic P2RY receptors in neonatal cultured microglia and evokes outwardly rectifying membrane currents. $\boldsymbol{A}$, Representative patch-clamp experiments on neonatal cultured microglia. Top, Cells were voltage-clamped at $-20 \mathrm{mV}$. A series of pulses ranging from -140 to $60 \mathrm{mV}$ were applied every $5 \mathrm{~s}$. TLQP21 at concentrations of $1 \mathrm{~nm}$ (left), $10 \mathrm{~nm}$ (middle), and $100 \mathrm{~nm}$ (right) was applied as indicated. Traces are all from the same recording. $\boldsymbol{B}$, Average current density-voltage relationships of TLQP21-evoked currents, at $1 \mathrm{~nm}$ (light gray), $10 \mathrm{~nm}$ (gray), and $100 \mathrm{~nm}$ (green). $n=7$ for each concentration. $C$, Summary of outward conductances $\left(G_{\text {outward }}\right)$ determined between 20 and $60 \mathrm{mV}$ evoked by TLQP21 at different concentrations. $\boldsymbol{D}, \boldsymbol{E}$, Time courses of representative patch-clamp experiments on microglia. Cells were voltage-clamped at $-20 \mathrm{mV}$. Series of pulses ranging from -160 to $60 \mathrm{mV}$ were applied every $5 \mathrm{~s}$. Either $10 \mu \mathrm{m}$ ATP (D) or $1000 \mu \mathrm{m} \mathrm{ATP}(\boldsymbol{E})$ was applied as indicated without prior TLQP21 application (Control) and 5 min after a 1 min TLQP21 application (After TLQP21). All occur due to the activation of microglial P2Y and P2X receptors, respectively. $F, G$, Average current density to voltage (CD-V) relationships of currents induced by $10 \mu \mathrm{m}(\boldsymbol{F})$ or $1000 \mu \mathrm{M}$ (G) ATP without (black) or with (green) prior TLQP21 application. $\boldsymbol{E}$, currents. After TLQP21 application, there was a significant decline in the amplitudes of P2RY responses, but not of P2RX responses. ${ }^{* * * *} p<0.001$. n.s., Not significant $(p>0.05)$. See Figure 2-1).

recordings when TLQP21 was not applied, indicating that TLQP21 leads to an impairment of P2Y signaling. While at concentrations of $10 \mu \mathrm{M}$ ATP only P2Y receptors are activated, at $1000 \mu \mathrm{M}$ ATP also ionotropic P2X receptors are activated, in particular $\mathrm{P}_{2} \mathrm{RX}_{7}$, the most common P2XR isoform in microglia, which conducts inwardly rectifying cationic currents. Thus, application of $1000 \mu \mathrm{M}$ ATP activated a large membrane conductance, which reversed at $0 \mathrm{mV}$ (Fig. $1 G$ ). We quantified currents in response to $1000 \mu \mathrm{M}$ ATP $55 \mathrm{~s}$ after wash-in of ATP and found no differences between experiments with and without a previous application of TLQP21.

The impairment of microglial P2RY responses by TLQP21 in brain slices might be the result of TLQP21 action either directly 
A
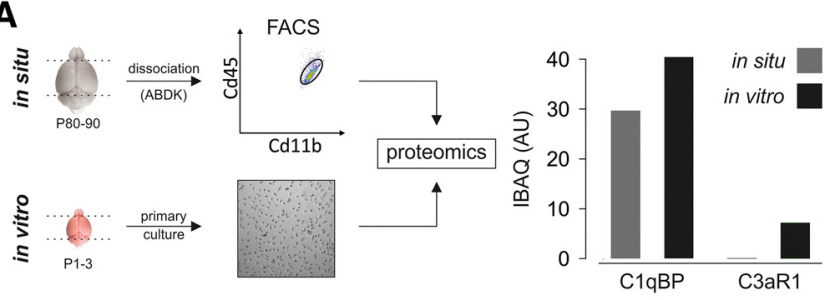

B

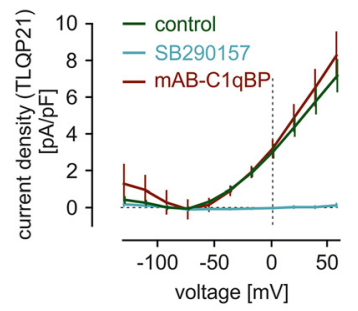

C

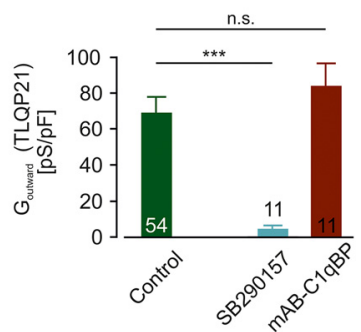

D

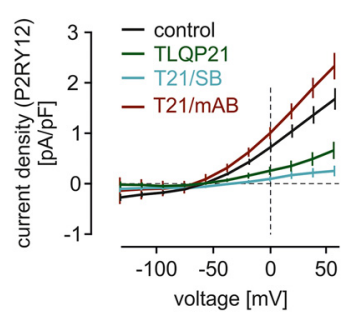

E

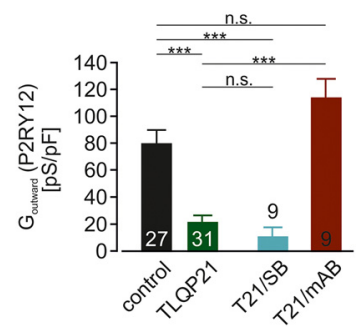

Figure 3. C3aR1 and C1qBP expression on microglia and their differential contribution to TLQP21 responses. $A$, Proteomic analysis of cultured and freshly isolated microglia demonstrates robust expression of $\mathrm{C} 1 \mathrm{qBP}$ and reveals differential expression of C3aR1. Left, Scheme depicting the sample generation. To test microglial protein expression under in situ conditions, we freshly isolated microglia from adult male C57BL/6 mice by FACS. Microglia were first gated as CD11b ${ }^{+}$cells against forward scatter and subsequently selected as $C D 45^{\text {low }}$ expressing cells $\left(C D 11 b^{+}\right.$CD45 $\left.{ }^{\text {low }}\right)$. Protein from primary cultured microglia was directly isolated. Right, Protein expression of $\mathrm{C} 1 \mathrm{qBP}$ and $\mathrm{C} 3 \mathrm{aR} 1$ as iBAQ intensity of each protein. $\mathrm{C} 1 \mathrm{qBP}$ was found in both microglia preparations, whereas there was no C3aR1 detected in freshly isolated microglia. B, C, TLQP21 current responses were recorded as shown in Figure $2 A$ in primary cultured microglial cells. The C3aR1-specific inhibitor SB290157, but not C1qBP blockade by a monoclonal antibody (mAB-C1qBP), prevented microglial responses upon TLQP21, as demonstrated in the summarized current density to voltage (CD-V) relationships of TLQP21 responses $(\boldsymbol{B})$ and the respective outward conductances $\left(\mathrm{G}_{\text {outward }}\right)$ determined between 20 and $60 \mathrm{mV}(\boldsymbol{C}) . \boldsymbol{D}, \boldsymbol{E}$, Current density to voltage (CD-V) relationships $(\boldsymbol{D})$ and outward conductances $(\boldsymbol{E})$ of microglial metabotropic ATP responses (10 $\mu \mathrm{M}$ ) under control conditions (no TLQP21 application, control), after TLQP21 application and after TLQP21 application while blocking either C3aR1 or C1qBP. The decrease in metabotropic ATP responses depends on TLQP21 action on microglial C1qBP. ${ }^{* * *} p<0.001$. n.s., Not significant $(p>0.05)$.

on microglial cells or indirectly on nonmicroglial cells, such as neurons or astrocytes. To test for microglial TLQP21 receptors and thus provide evidence for a direct action of TLQP21 on microglial cells, we next investigated primary cultured microglial cells. We performed patch-clamp experiments and studied the TLQP21-evoked decreases in purinergic signaling (Fig. 2). In contrast to slices, application of $100 \mathrm{nM}$ TLQP21 directly triggered outwardly rectifying currents (Fig. $2 A, B$ ), which reversed close to the Nernst potential for $\mathrm{K}^{+}$. The specific outward conductance of these currents between 20 and $60 \mathrm{mV}$ was $57.8 \pm 11.0$ $\mathrm{pS} / \mathrm{pF}$ (24 of 25 cells responding; Fig. 2C). Activation of these currents by TLQP21 was concentration-dependent, as it was lower at $10 \mathrm{nM}$ TLQP21 (8.1 $\pm 3.6 \mathrm{pS} / \mathrm{pF} ; 5$ of 13 cells responding $)$ and absent at $1 \mathrm{nM}$ TLQP21 $(n=11)$. We tested the effect of low $(10 \mu \mathrm{M})$ ATP concentrations to activate P2RY and high (1000 $\mu \mathrm{M})$ ATP concentrations to activate P2RX responses in cultured microglia. Similar to the responses in situ, low ATP concentrations triggered a $\mathrm{K}^{+}$conductance, whereas high concentrations triggered a cationic conductance as shown in Figure $2 D-F$. TLQP21 treatment significantly reduced currents evoked by $10 \mu \mathrm{M}$ ATP, indicating that the metabotropic (P2RY) component of microglial purinergic responses is considerably affected by

TLQP21. In some experiments, we observed that the inhibition of the $\mathrm{K}^{+}$conductance unmasks an underlying cationic conductance as shown in the example trace in Figure 2D. We also tested the impact of TLQP21 on P2X receptor currents (Fig. 2E,G). However, as in situ, there were no significant differences between P2XR currents under control conditions and after application of TLQP21 (Fig. $2 G$ ). In an attempt to further specify the identity of purinergic receptors activated at $10 \mu \mathrm{M}$ ATP, we tested the specific P2RY 12 inhibitor AR-C69931 (Fig. 2-1). In the presence of $1 \mu \mathrm{M}$ AR-C69931, outward currents upon $10 \mu \mathrm{M}$ ATP between -170 and $60 \mathrm{mV}$ were significantly reduced ( $p=0.0064$ to $0.0081 ; n=16$ ), indicating a major involvement of $\mathrm{P}_{2} \mathrm{RY}_{12}$ in mediating responses upon $10 \mu \mathrm{M}$ ATP. We conclude that TLQP21 evokes membrane currents in cultured microglia, but not in situ and that TLQP21 impairs P2Y, but not $\mathrm{P} 2 \mathrm{X}$ purinergic responses both in situ and in vitro.

\section{C1qBP and C3aR1 differentially contribute to TLQP21 actions on microglial cells}

In previous studies, two different receptors for TLQP21 were identified, C3aR1 and $\mathrm{ClqBP}$, both belonging to the complement receptor system (Chen et al., 2013; Hannedouche et al., 2013). We hypothesized that these two receptors could be responsible for the effects of TLQP21 on microglia purinergic signaling in vitro and in situ. We compared the protein expression levels of C3aR1 and C1qBP in situ and in vitro by proteomics. Data for in situ microglia $\left(\mathrm{CD} 11 \mathrm{~b}^{+} \mathrm{CD} 45^{\text {low }}\right)$ were obtained from microglial cells isolated by FACS from 12-weekold naive C57BL/6J male mice; in vitro data were obtained from neonatal cultured microglia. Protein expression levels of C3aR1 and $\mathrm{ClqBP}$ were calculated from the measured $\mathrm{BBAQ}$ intensities. As shown in Figure 3A, protein expression of C1qBP was equally high in cultured and freshly isolated microglia, whereas C3aR1 was detected in primary cultured microglia only. These data confirm a previously published proteomic screen (Sharma et al., 2015) and provide evidence for two different receptor systems that potentially mediate TLQP21 actions on microglia.

We next used the patch-clamp technique and used inhibitors for C3aR1 (SB290157) and C1qBP (an anti-C1qPB monoclonal antibody; $\mathrm{mAB}-\mathrm{ClqBP}$ ) to test whether or not these receptors are involved in the differential effects of TLQP21 on microglia. TLQP21-evoked currents were blocked by SB290157 inhibition ( 10 of 11 cells; Fig. $3 B, C$ ), indicating that these currents are activated downstream of C3aR1. Only in one cell, a small TLQP21 response was detected in the presence of the antagonist with an outward conductance of only $25 \%$ of the average TLQP21 response. To block $\mathrm{C} 1 \mathrm{qBP}$ receptors, cultured microglia were incubated in $\mathrm{mAB}-\mathrm{C} 1 \mathrm{qBP}$-containing medium $(3 \mu \mathrm{g} / \mathrm{ml})$ for 
40-60 min before the patch-clamp recordings. However, mAB-C1qBP treatment did not affect TLQP21-induced currents (Fig. $3 B, C$ ). We therefore conclude that TLQP21 evokes outwardly rectifying potassium currents in microglial cells via $\mathrm{C} 3 \mathrm{aR} 1$, but not via $\mathrm{C} 1 \mathrm{qBP}$.

We then investigated whether the TLQP21-evoked decrease of microglial $\mathrm{P} 2 \mathrm{Y}$ responses is mediated by either $\mathrm{C} 3 \mathrm{aR} 1$ or $\mathrm{C} 1 \mathrm{qBP}$. The blockade of C3aR1 did not prevent the TLQP21-induced inhibition of ATP-evoked outward potassium currents. When TLQP21 (100 nM) was applied together with SB290157 (1 $\mu \mathrm{M})$, subsequent ATP-evoked outward currents were still significantly reduced $\left(\mathrm{G}_{\text {out }}=10.4 \pm 7.3 \mathrm{pS} / \mathrm{pF} ; n=9 ; p=\right.$ 0.0003 to control ATP responses; Fig. $3 D, E)$, indicating that SB290157 does not prevent the impact of TLQP21 on ATPinduced currents. To test for the involvement of $\mathrm{C} 1 \mathrm{qBP}$, we preincubated microglia with $\mathrm{mAB}-\mathrm{C} 1 \mathrm{qBP}(3 \mu \mathrm{g} / \mathrm{ml})$ for 40-60 min before recording. Interestingly, after that treatment, we observed a complete recovery of $\mathrm{P} 2 \mathrm{Y}$ responses $\left(\mathrm{G}_{\text {out }}\right.$ $=113.3 \pm 14.4 \mathrm{pS} / \mathrm{pF} ; n=9 ; p=0.1289$ to control ATP responses; Fig. $3 D, E$ ), indicating that the impairment of microglial purinergic responses by TLQP21 is mediated by signaling through $\mathrm{ClqBP}$, but not C3aR1.

\section{TLQP21 induces intracellular calcium elevations in microglia via C3AR1}

We tested the effects of TLQP21 $(1,10$, and $100 \mathrm{~nm}$ ) on intracellular $\mathrm{Ca}^{2+}$ levels in neonatal cultured microglia. TLQP21 was applied for $30 \mathrm{~s}$ on microglia loaded with Fluo-4 (Fig. 4A). In accordance to Korvers et al. (2016), microglia exhibited a moderate level of spontaneous $\mathrm{Ca}^{2+}$ elevations under basal conditions, resulting in an overall basal responsiveness of $10.8 \pm 1.7 \%$ during a recording period of $30 \mathrm{~s}(n=4909$ cells/44 exp). When 1,10 , or $100 \mathrm{~nm}$ TLQP21 was applied, on average $56.9 \pm 10.0 \%(p=0.0011 ; n=1401$ cells/10 exp), $39.1 \pm 10.2 \%(p=0.0482 ; n=100$ cells $/ 5 \exp )$, and $44.8 \pm 10.8 \%(p=0.0056 ; n=1267$ cells $/ 14 \exp )$ of the cells responded, indicating that TLQP21 increases intracellular calcium levels in microglia (Fig. $4 B-D$ ). Intracellular $\mathrm{Ca}^{2+}$ increases upon TLQP21 had diverse time courses ranging from a constant increase over the whole application period to periodically occurring transients, which sometimes even persisted after TLQP21 washout. We quantified the maximum amplitudes of microglial TLQP21 responses and normalized them to the amplitudes evoked by ATP $(500 \mu \mathrm{M})$, which were measured at the end of each experiment. As shown in Figure $4 D$, amplitudes in the presence of 1,10 , and $100 \mathrm{~nm}$ TLQP2 1 were $25.5 \pm 8.7 \%(p=0.0251 ; n=$ 1401 cells $/ 10 \exp ), 36.6 \pm 10.3 \%(p=0.0274 ; n=100$ cells $/ 5$ $\exp )$, and $37.1 \pm 8.9 \%(p=0.0018 ; n=1267$ cells $/ 14 \mathrm{exp})$,
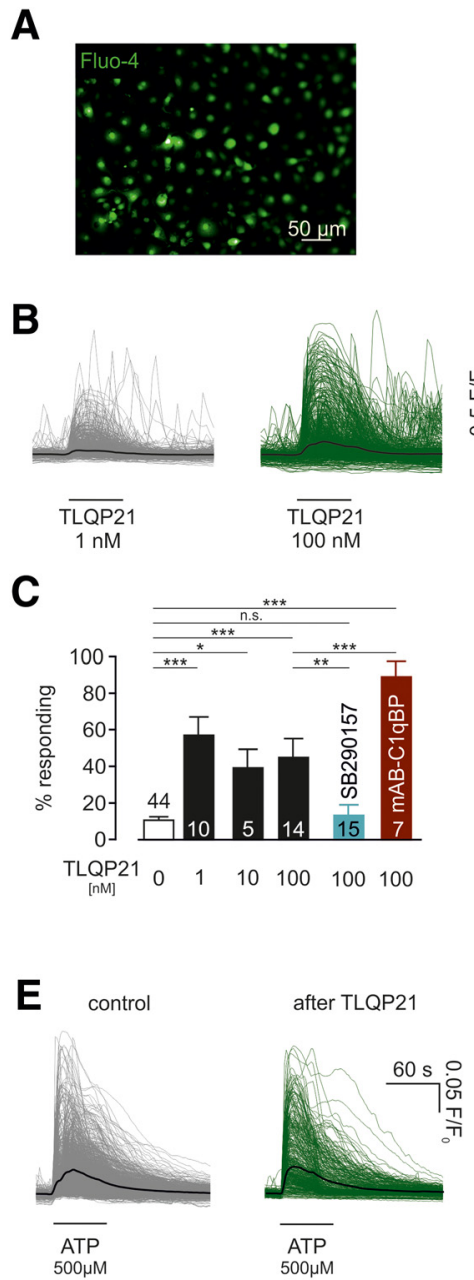
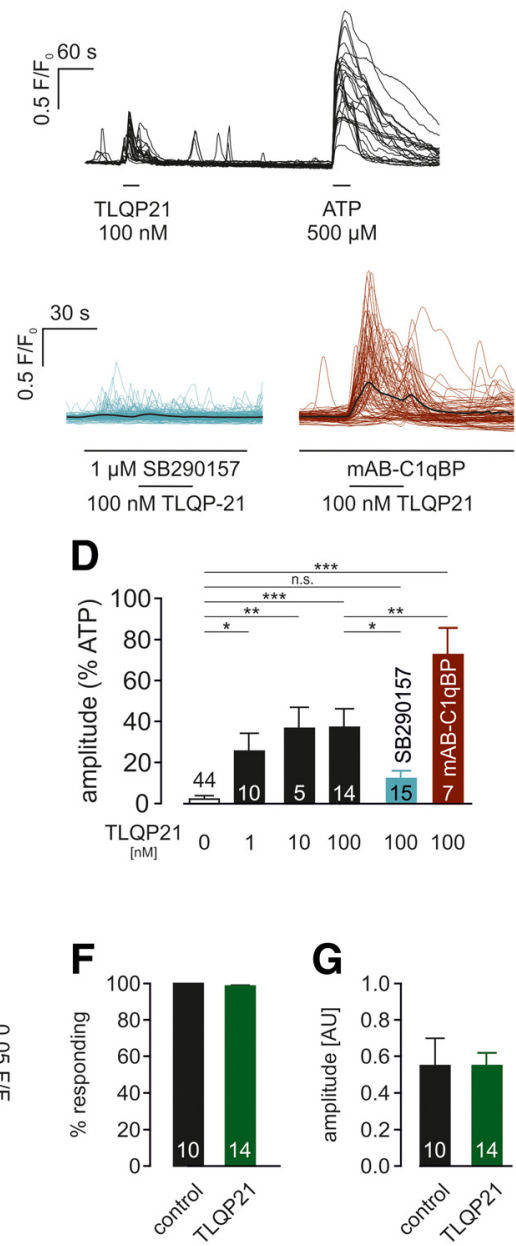

Figure 4. TLQP21 induces intracellular calcium elevations in microglia via C3aR1. $\boldsymbol{A}$, Left, Cultured neonatal microglia were loaded with Fluo4 to measure cytosolic $\mathrm{Ca}^{2+}$ level changes fluorometrically. The image shows the Fluo4 fluorescence. Right, Representative $\mathrm{Ca}^{2+}$ imaging experiment, corresponding to the image shown on the left. Traces are superimposed from $24 \mathrm{ROls}$, respective microglial cells; $100 \mathrm{~nm}$ TLQP21 and $500 \mu \mathrm{m}$ ATP were applied as indicated by the bars. $\boldsymbol{B}, 0$ verlay of all microglial $\mathrm{Ca}^{2+}$ traces obtained upon $1 \mathrm{~nm}$ (left) and $100 \mathrm{~nm}$ (middle left) TLQP21, as well as upon $100 \mathrm{~nm}$ TLQP21 in the presence of either $1 \mu \mathrm{m}$ SB290157 (middle right) or mAB-C1qBP (right). C, Summary of percentage of microglia responding upon TLQP21 at different (Korvers et al., 2016), responding microglia in the absence of TLQP21 are also summarized ("0 nm TLQP21"). D, Summary of the amplitudes evoked by TLQP21 at different concentrations in the absence and presence of SB290157 or mAB-C1qBP. Amplitude of 2016), basal amplitudes were also summarized ("0 nm TLQP21"). E, Overlay of microglial $\mathrm{Ca}^{2+}$ responses upon $500 \mu \mathrm{M}$ ATP with

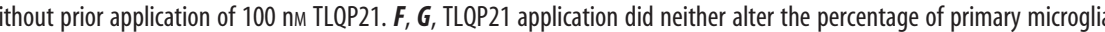
responding to subsequent ATP applications $(\boldsymbol{F})$ nor the amplitude of the ATP responses $(\boldsymbol{G}) .{ }^{*} p<0.05 .{ }^{* *} p<0.01 .{ }^{* *} p<0.001$. n.s., Not significant $(p>0.05)$.

respectively, and therefore significantly larger than baseline $\mathrm{Ca}^{2+}$ fluctuations $(2.1 \pm 1.7 \%, n=4909$ cells/44 exp). We also tested the effects of the C3AR1 antagonist SB290157 (1 $\mu \mathrm{M})$ on TLQP21-evoked $\mathrm{Ca}^{2+}$ responses in microglia. We found that only $13.2 \pm 5.7 \%$ of cells responded to $100 \mathrm{nM}$ TLQP2 1 in the presence of SB290157 ( $n=2141$ cells/15 exp), which was significantly different from $100 \mathrm{~nm}$ TLQP21 alone $(p=0.0142)$, but not from baseline $(p=0.6600)$. The maximal $\mathrm{Ca}^{2+}$ amplitudes upon $100 \mathrm{~nm}$ TLQP21 in the presence of SB290157 (12.2 $\pm 3.8 \%$; $p=0.0254 ; n=2141$ cells $/ 15$ exp) were significantly smaller than in the absence of SB290157 (37.1 $\pm 9.0 \% ; n=1267$ cells/ 14 exp; $p=0.0237)$, and not different from control conditions $(2.1 \pm$ $1.7 \% ; n=4909$ cells $/ 44$ exp; $p=0.5960$ ). We also tested the effect of $\mathrm{ClqPB}$ blockade on microglial $\mathrm{Ca}^{2+}$ responses upon $100 \mathrm{nM}$ 
A
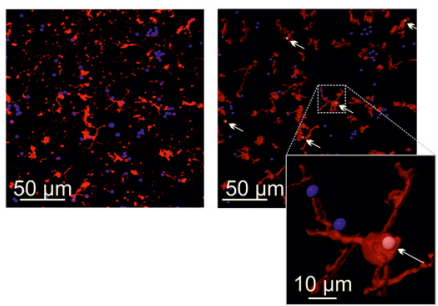

B
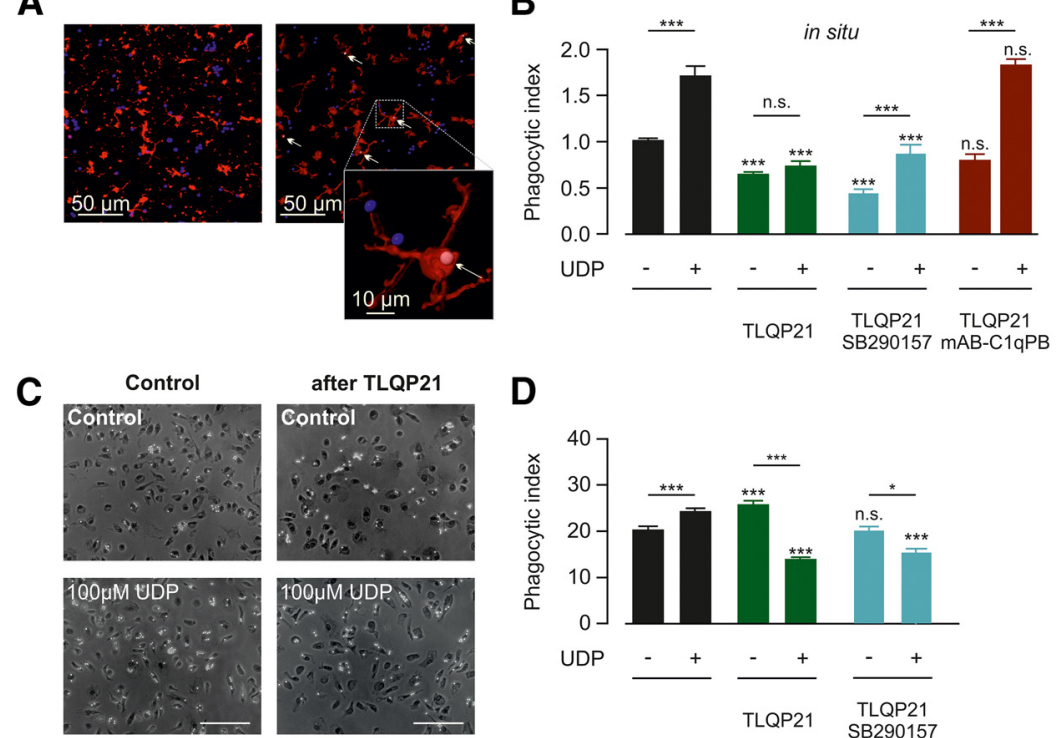

Figure 5. TLQP21 affects microglial phagocytic activity. A, Phagocytosis assay in situ. Representative confocal image (left) of Iba1-stained microglia (red) after 60 min incubation with latex beads (blue) performed on a cortical brain slice from a 14 week BI6 mouse. Right, $3 \mathrm{D}$ reconstruction of Iba1-positive microglia is shown with automatically counted phagocytosed beads (shown in white and indicated by arrows). Scale bar, $50 \mu \mathrm{m}$. Inset, Magnification of a 3D-rendered microglial cell that incorporates a latex bead. Color code as in the large images. Scale bar, $10 \mu \mathrm{m}$. B, Summary of microglial phagocytosis in cortical brain slices (in situ). Control phagocytosis in the absence of UDP ( - ) was decreased by preincubation with TLQP21. This decrease was rescued by C1qBP blockade (mAB-C1qBP) but not affected by C3aR1 blockade (SB290157). In the presence of $100 \mu \mathrm{M}$ UDP (+), phagocytosis was stimulated under control conditions, an effect that was prevented by pretreatment with TLQP21 (100 nM). C1qBP blockade (mAB-C1qBP), but not C3aR1 blockade (SB290157) during TLQP21 incubation restored UDP stimulation of microglial phagocytosis. The significance level above the bars refers to the control value with or without UDP. C, To determine phagocytic activity in culture, primary microglia were incubated with fluorescent microbeads (YFP) subsequent to preincubation with TLQP21 (100 nM) or PBS (Control) for $30 \mathrm{~min}$, fixed, and stained for Iba1. Representative images for these conditions are shown. D, Microglial phagocytic indices (mean $\pm \mathrm{SEM}$ ) under control- and UDP-stimulating conditions. TLQP21 enhanced microglial phagocytosis under control conditions (-), and this stimulation was blocked by coincubation with C3aR1 antagonist SB290157. Preincubation with TLQ21 decreased the UDP-induced stimulation of microglial phagocytosis $(+)$, which was not prevented by C3aR1 blockade (SB290157). The significance level above the bars refers to the control value with or without UDP. ${ }^{*} p<0.05,{ }^{* * *} p<$ 0.001 . n.s., Not significant $(p>0.05)$. See Figure 5-1.

TLQP21. The incubation of microglia for $30 \mathrm{~min}$ with $\mathrm{mAB}-$ C1qBP $(3 \mu \mathrm{g} / \mathrm{ml}$ ) did not lead to a decrease but even to an increase of TLQP21 responses $(89.0 \pm 8.4 \%, n=171$ cells $/ 7$ exp; $p=0.0008$ compared with $100 \mathrm{~nm}$ TLQP21) and relative amplitudes $(72.7 \pm 13.0 \% ; p=0.0056$ compared with $100 \mathrm{nM}$ TLQP21). Together, these data show that TLQP21 evokes intracellular $\mathrm{Ca}^{2+}$ elevations via C3aR1 activation.

We additionally looked at the impact of TLQP21 application on subsequent ATP-evoked $\mathrm{Ca}^{2+}$ responses (Fig. 4E,F). However, no differences were found in either the percentage of microglia responding to $500 \mu \mathrm{M}$ ATP or in the amplitude of ATP-induced cytosolic $\mathrm{Ca}^{2+}$ increases. Thus, TLQP21 attenuates microglial ATP-evoked membrane currents but not ATP-evoked intracellular $\mathrm{Ca}^{2+}$ elevations.

\section{TLQP21 differentially affects the phagocytic activity in vitro and in situ}

To study the effect of TLQP21 on P2Y-mediated functions in microglia, we analyzed UDP-stimulated phagocytosis in situ. It was previously shown that microglial phagocytosis is stimulated though $\mathrm{P}_{2} \mathrm{Y}_{6} \mathrm{R}$ activation by UDP (Koizumi et al., 2007; Xu et al., 2016; Wendt et al., 2017). We incubated acute brain slices from male C57BL/6J mice (14 weeks) for $60 \mathrm{~min}$ with fluorescent latex beads and subsequently stained for labeled microglia with antiIba1. Confocal imaging and $3 \mathrm{D}$ reconstruction (Fig. 5A) were used to quantify the number of beads that were incorporated into a 3D-rendered Iba1-labeled volume, which allowed us to calculate the phagocytic index of microglia (see Materials and Methods). As shown in Figure $5 B$, baseline microglial phagocytosis $(1.00 \pm 0.06 ; n=21)$ was indeed significantly increased when UDP $(100 \mu \mathrm{M})$ was coapplied together with the beads $(1.67 \pm 0.1 ; n=21 ; p<0.0001)$. Interestingly, preincubation (i.e., before the incubation with the beads) of the slices for $60 \mathrm{~min}$ with $100 \mathrm{nM}$ TLQP21 decreased the phagocytic activity of microglia $(0.66 \pm 0.05 ; n=21 ; p=$ $0.0001)$, suggesting that a downregulation of microglial purinergic signaling is affecting the basal phagocytic activity. Furthermore, UDP stimulation of microglia completely failed after TLQP21 treatment $(0.74 \pm 0.05 ; n=21 ; p=$ $0.0001)$. Preincubation of the slices with TLQP21 $(100 \mu \mathrm{M})+$ SB290157 $(1 \mu \mathrm{M})$ did not alter microglial phagocytosis compared with TLQP21 preincubation alone $(0.81 \pm 0.08 ; n=12 ; p=0.06)$, indicating that the impairment of $\mathrm{mi}-$ croglial purinergic signaling by TLQP21 occurs independently of C3aR1 and confirming again the lack of functional C3aR1 receptors on microglia in situ. To check for the involvement of C1qBP, slices were preincubated with TLQP21 + $\mathrm{mAB}-\mathrm{C} 1 \mathrm{qBP}$. This treatment did rescue both the TLQP21-dependent decline in basal phagocytosis (Fig. $5 B$ ) as well as the TLQP21-derived impairment of UDP-stimulated phagocytosis (1.72 \pm $0.15 ; n=12 ; p<0.0001$ compared with Control/TLQP21; Fig. $5 B)$. Thus, TLQP21 impairs microglial phagocytic activity in situ in a C1qBP-dependent fashion.

We also tested whether TLQP21 affects microglial phagocytic activity and UDP stimulation of phagocytosis in vitro. Consistent with previous reports (Koizumi et al., 2007), 30 min incubation of microglia with $100 \mu \mathrm{M}$ UDP significantly increased their phagocytic activity (from $19.3 \pm 0.7$ to $23.9 \pm$ $0.8 ; n=36 ; p=0.0016$; Fig. $5 C, D)$. We preincubated microglia for $30 \mathrm{~min}$ with TLQP21 (100 nM) and quantified their phagocytic activity. TLQP21 treatment caused a significant increase in microglial phagocytic activity to $24.6 \pm 0.9(n=$ 34; $p=0.0032$ compared with control), indicating that TLQP21 directly stimulated phagocytosis. The UDP-evoked stimulation of microglial phagocytosis was, however, prevented by a $30 \mathrm{~min}$ pretreatment with $100 \mu \mathrm{M}$ TLQP21 (16.6 $0.6 ; n=36 ; p<0.0001$ compared with UDP without pretreatment), and this could not be restored by C3aR1 blockade $(17.4 \pm 0.9 ; n=33 ; p<0.0001$ compared with UDP without pretreatment). Thus, in culture, TLQP21 has two effects: a direct stimulation of phagocytic activity and an impairment of the purinergic control of microglial phagocytosis.

To confirm that TLQP21 not only affects ATP mediated signaling, but also UDP-dependent signaling, we used the patch- 
clamp technique and tested the effect of 100 nM TLQP21 on subsequent UDPmediated membrane currents and $\mathrm{Ca}^{2+}$ responses (Fig. 5-1A). As for $10 \mu \mathrm{M}$ ATP (see above), also UDP $(100 \mu \mathrm{M})$ reliably evoked outwardly rectifying membrane currents $\left(\mathrm{G}_{\text {out }}=8.2 \pm 2.0 \mathrm{pS} / \mathrm{pF} ; n=10\right.$; Fig. 5-1B), which reversed close to the Nernst potential for $\mathrm{K}^{+}(-82.2 \pm 8.3$ $\mathrm{mV} ; n=10)$. However, when $100 \mathrm{nM}$ TLQP21 was applied 5 min before UDP application, UDP-evoked outward currents were significantly smaller $\left(\mathrm{G}_{\text {out }}=\right.$ $1.4 \pm 2.9 \mathrm{pS} / \mathrm{pF} ; n=8 ; p=0.0357$; Fig. 5-1B).

TLQP21 triggers chemotaxis and inhibits ATP-induced migration We studied the impact of TLQP21 on microglial migration and first tested whether there is chemotaxis toward TLQP21. We used an agarose spot assay, in which the agarose was mixed with three different concentrations of TLQP21 to create a gradient from the agarose spot to the surrounding medium (Fig. 6A). After a $3 \mathrm{~h}$ incubation, 10 and $100 \mathrm{~nm}$ TLQP21 significantly increased the percentage of microglia migrating into the agarose area compared with control spots without TLQP2 1 in the same well to $3.1 \pm 0.5$ and to $2.5 \pm 0.4$, respectively $(p=0.0008,15-23$ spots from four independent biological replicates). Migration into spots containing $1 \mathrm{nM}$ TLQP2 1 was only $2.1 \pm 0.3$-fold higher than into PBScontaining spots (not significant). We verified these results using the Boyden chamber assay (Fig. 6-1A). TLQP21 at concentrations of 1, 10, or $100 \mathrm{~nm}$ were added in the bottom of the Boyden chamber to generate a TLQP21 gradient. The percentage of cells that migrated to the bottom of the chamber through the membrane within $3 \mathrm{~h}$ was quantified in relation to a control (no TLQP21). There was a significant increase of cells in the lower well with $100 \mathrm{nM}$ TLQP21 (3.0 \pm 0.5 -fold increase compared with control; $p=0.0006 ; n=4)$, whereas 1 and $10 \mathrm{nM}$ did not significantly differ from control. There was no chemotaxis toward a gradient of scrambled peptide (100 nM) ( $p=0.6000$; Fig. 6- $1 A)$, excluding unspecific peptide effects on microglial migration.

We also tested whether TLQP21 influences microglial undirected motility by ablating the concentration gradient in the agarose spot experiments (Fig. 6A). TLQP21 at concentrations of 10 and $100 \mathrm{~nm}$ was added to both the spot and the medium, thus disseminating the gradient. This did not increase microglial migration $(1.0 \pm 0.1 ; p=0.3863 ; n=6$ for $10 \mathrm{nM}$ TLQP21 spots and $1.0 \pm 0.3 ; p=0.1139 ; n=8$ for $100 \mathrm{nM}$ TLQP21 spots vs PBS-containing spots), indicating that TLQP21 does not increase microglial motility. This finding was confirmed in Boyden chamber assays when applying TLQP21 in both upper and lower chamber, thus with no gradient. Neither 10 nM nor 100 nM TLQP21 led to a significant increase in microglial motility $(p=0.8100$; Fig. 6-1A). The scratch wound assay was used as another general cellular motility assay: TLQP21 was added to the culture medium and the number of microglial cells, which moved toward the cell-free area within $3 \mathrm{~h}$ was compared with control (Fig. 6-1B). At 1, 10, and $100 \mathrm{~nm}$ TLQP21, the number of cells in the cell-free area was $1.1 \pm 0.3-, 1.5 \pm 0.5$-, and $1.8 \pm 0.2$-fold compared with control and therefore not significantly changed $(n=9$; Fig. $6-1 B)$. This again validates our previous findings that TLQP21 mediates microglial chemotaxis but does not influence microglial motility.

Microglia migration is stimulated by purinergic signaling. We thus aimed to study whether TLQP21 would interfere with ATPinduced migration (Fig. 6B), and performed an agarose spot assay. We first quantified the migration toward ATP under control conditions: ATP (1 mM) and control (PBS) spots were placed in dishes together with untreated microglial cells. During $3 \mathrm{~h}$ of incubation time, microglia migrated preferentially toward the ATP-containing spots (7.1 \pm 0.7 -fold compared with PBScontaining spots; $p<0.0001 ; n=16)$. Intriguingly, when microglia were incubated with $100 \mathrm{nM}$ TLQP21, the preference for ATP-containing spots after $3 \mathrm{~h}$ was eliminated. The average preference for ATP-containing spots was only $0.55 \pm 0.03$ after TLQP21 treatment and therefore significantly smaller than in control experiments without TLQP21 ( $p=0.0001 ; n=45)$. Thus, TLQP21 impairs microglial chemotaxis toward ATP. We finally applied agarose spot assays to test for the involvement of C3aR1 and C1qBP in the TLQP21-mediated effects on microglial chemotaxis. Interestingly, the blockade of C3aR1 by SB290157 $(1 \mu \mathrm{M})$ significantly reduced microglial migration toward TLQP21 (1.5 \pm 0.1 -fold compared with PBS spots; $p=$ $0.0047 ; n=9$; Fig. $6 A$ ) but did not restore the TLQP21-mediated loss in migration toward ATP $(0.56 \pm 1.27$ relative to PBS spots; $n=11$; Fig. $6 B$ ). On the other hand, incubating the cells with a combination of $100 \mathrm{~nm}$ TLQP21 and mAB-C1qBP $(1.5 \mu \mathrm{g} / \mathrm{ml})$ restored the migration of microglial cells toward ATP-containing agarose spots $(2.5 \pm 0.22$ relative to PBS; $p<0.0001 ; n=11$; Fig. $6 B)$. We conclude that microglial chemotaxis toward TLQP21 
A
Control
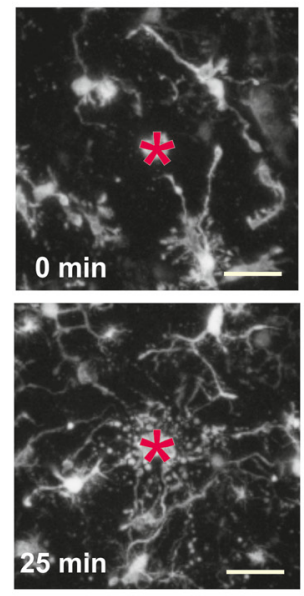

B
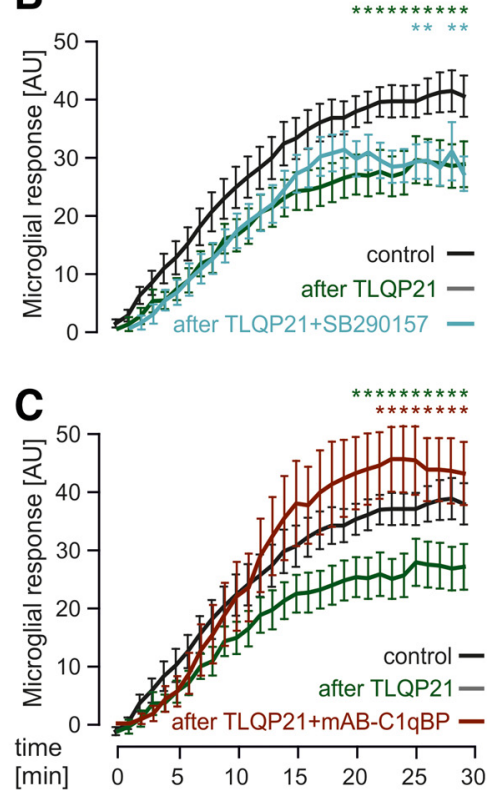

Figure 7. TLQP21 decreases microglial-directed process movement in a C1qBP-dependent manner. $\boldsymbol{A}$, Representative pictures of injury-induced process movement of EGFP-positive microglia in the cortex of acute brain slices from MacGreen mice under control conditions (left panels) and after preincubation with $100 \mathrm{~nm}$ TLQP21 (right panels). Acute injury was induced by a laser lesion (red asterisk), and microglial responses were observed for $30 \mathrm{~min}$. Images were taken using 2-photon microscopy at 0 min (top, directly after setting the laser lesion) and $25 \mathrm{~min}$ later (bottom). Scale bars, $20 \mu \mathrm{m}$. B, Quantitative analysis of injury-induced process motility in control conditions, after preincubation with TLQP21 (100 nM) or TLQP21(100 nM) + SB290157 (1 $\mu \mathrm{M})$. The microglial-directed process movement was significantly slower after pretreatment with TLQP21 (100 nM), which could not be rescued by blockade of C3aR1. Green and blue asterisks indicate the Tukey comparisons "Control" versus "after TLQP21" and "Control" versus "after TLQP21 + SB290157," respectively. The conditions "after TLQP21" and "after TLQP21 + SB290157" were not significantly different. C, Same as in B, but using mAB-C1qBP (3 $\mu \mathrm{g} / \mathrm{ml})$ instead of SB290157. C1qBP blockade rescued the TLQP21-induced reduction in directed process motility. Green and red asterisks indicate the Tukey comparisons "Control" versus "after TLQP21" and "after TLQP21" versus "after TLQP21 + mAB-C1qBP," respectively. The conditions "Control" and "after TLQP21 + mAB-C1qBP" were not significantly different. ${ }^{*} p<0.05$.

depends on C3aR1, and the TLQP21-mediated loss in chemotaxis toward ATP depends on C1qBP.

\section{TLQP21 decreases microglial process movement toward a microlesion}

We finally investigated the chemotactic movement of microglial processes that depends on extracellular ATP/ADP and signaling through P2RY 12 (Davalos et al., 2005; Nimmerjahn et al., 2005; Haynes et al., 2006). As TLQP21 affects microglial purinergic signaling, we expected a decrease in processes movement. We used MacGreen mice, which express an EGFP transgene under the Csf1R1 promoter to identify microglial cells (Sasmono et al., 2003). The movement of microglial processes was quantified by determining the fluorescence distribution within concentric circles (45 and $240 \mu \mathrm{m}$; Fig. 6A) around the lesion site. During the 30 min recording time after the laser lesion, the microglial processes moved toward the lesion site, resulting in an increase in fluorescence in the areas closer to the lesion site, which then was quantified as described in Materials and Methods (40.9 \pm 3.6, $n=16$; Fig. $7 A, B)$ under control conditions. The preincubation of brain slices with TLQP21 (100 nM) for $60 \mathrm{~min}$ before the induction of the laser lesion (Fig. 7A-C) led indeed to a reduction of these responses to $28.7 \pm 4.0(n=12, p=0.0370)$, indicating a TLQP21-mediated decline of microglial purinergic responses. This impairment could not be restored by the C3aR1 inhibitor SB290157 (26.9 $\pm 3.0 ; n=13, p=0.0318$ to control; $p=0.9806$ to TLQP21; Fig. $7 B$ ). However, blockade of C1qBP by preincubating the slices with TLQP21 and mAB-C1qBP led to a rescue of microglial process movement toward the lesion site that was not significantly different from control conditions $(44.7 \pm 5.1 ; n=13$, $p=0.5303$ to control; $p=0.0008$ to TLQP21; Fig. 7C). These experiments provide further evidence that TLQP21 acts via C1qBP to downregulate purinergic signaling in microglia.

\section{Discussion}

In the present study, we demonstrate that the VGF-derived peptide TLQP21 affects microglial function via two distinct pathways linked to distinct microglial features: (1) via a C1qBP-dependent pathway resulting in a downregulation of purinergic signaling through metabotropic P2Y receptors; and (2) via a C3aR1-dependent pathway activating membrane currents, $\mathrm{Ca}^{2+}$ responses, and stimulating migration and phagocytic activity. The C1qBPdependent impairment of purinergic responses results in a reduction of membrane currents evoked by metabotropic $\mathrm{P} 2 \mathrm{Y}$ receptors, chemoattractance by ATP, and the stimulation of microglial phagocytosis by UDP. Intriguingly, purinergic responses were affected even minutes after washout of TLQP21, indicating that $\mathrm{C} 1 \mathrm{qBP}$-dependent signaling results in a long-term change in microglial properties.

To our knowledge, $\mathrm{C} 1 \mathrm{qBP}$ is the first receptor that has a long-term modulating effect on microglial purinergic responses. Previous studies on TLQP21 and its receptors described $\mathrm{Ca}^{2+}$ responses in microglia (Chen et al., 2013; Hannedouche et al., 2013; Molteni et al., 2017). In these studies and in ours, the ATPinduced $\mathrm{Ca}^{2+}$ responses were not attenuated by TLQP21 (Fig. 4). In the present study, we found that TLQP21 also acts, in addition to $\mathrm{C} 1 \mathrm{qBP}$, on another receptor, the G-protein-coupled complement receptor C3aR1. C3aR1 activation by TLQP21 triggered outwardly rectifying $\mathrm{K}^{+}$currents, intracellular $\mathrm{Ca}^{2+}$ elevations, and C3aR1 was found to be responsible for chemotaxis and TLQP21 stimulation of phagocytic activity. However, all these stimulating effects of TLQP21 were only found in primary cultured microglia but not in situ, consistent with the finding that the robust $\mathrm{C} 3 \mathrm{aR} 1$ protein expression in cultures was lacking in freshly isolated microglia. This intriguing difference might arise either from the fact that our primary cultures are derived from neonatal mice, whereas freshly isolated in situ microglia in this study are adult or from the culture environment that more mimics a pathologic situation. A previous proteomic study also detected $\mathrm{C} 3 \mathrm{aR} 1$ protein only in cultured but not freshly isolated microglia (Sharma et al., 2015). Surprisingly, on the mRNA level, recent transcriptomic studies report robust expression of the C3ar1 gene also in freshly isolated microglia (Hickman et al., 2013; Tabula Muris Consortium, 2018), suggesting that C3ar1 mRNA is either more prevalent or easier to detect than the protein.

Looking at nonphysiological states, microglial C3ar1 mRNA levels were found to be increased upon aging and under patho- 
logic conditions, including dementia, $\mathrm{AD}$, traumatic brain injury, and epilepsy (Hickman et al., 2013; Bodea et al., 2014; Zhao et al., 2018). This raises the intriguing possibility that functional C3aR1 protein expression could be induced by microglia activation, and that the stimulatory effects of TLQP21 in vivo become significant under disease conditions only. Indeed, recent studies demonstrated ameliorating effects in the tau pathology of an animal model of AD by deletion of C3aR1 (Litvinchuk et al., 2018) and a reduction in inflammatory microglial density after stroke by intracortical injection of SB290157 (Surugiu et al., 2019), the same C3aR1 blocker that was used in our study.

There are several studies demonstrating a correlation of VGFderived peptides and brain physiology, suggesting the intriguing possibility that microglial features are modulated by signaling through these peptides in vivo. The concentration of VGF peptides in the CSF is in the picomolar range (van Steenoven et al., 2019), which is lower by a factor of $10^{4}$ compared with the concentration we have used in the present study. The CSF concentration, however, most likely does not reflect the concentration in the brain parenchyma. Since VGF is preferentially expressed by neurons (Zhang et al., 2014), local concentrations of VGF and its peptides may reach levels as high as the ones used in our study, in particular at neuronal release sites.

We have recently demonstrated that microglial purinergic signaling is impaired in mouse models of $\mathrm{AD}$ (Wendt et al., 2017). Both functions, which are affected by pretreatment with the VGF-derived peptide TLQP21 in brain tissue, namely, the phagocytic activity and the process motility stimulated by purinergic signaling, are also impaired in these mouse models. Indeed, VGF is suggested as a potential biomarker for $\mathrm{AD}$ as VGF-derived peptides were found to be significantly decreased in the CSF of AD patients (Carrette et al., 2003; Hendrickson et al., 2015; Spellman et al., 2015).

TLQP21 is one of many bioactive peptides derived from posttranslational cleavage of VGF. Recent evidence suggests a comprehensive role of TLQP21 in neuronal network homeostasis and demonstrates the involvement of TLQP21 in many brain diseases, including psychiatric, neurodegenerative, and neuroinflammatory diseases (Alder et al., 2003; Severini et al., 2008; Sato et al., 2012; Lin et al., 2015; Sakamoto et al., 2015). Microglia, as the resident immune cells of the CNS, play an important role in any kind of brain disease (Wolf et al., 2017), and our data indicate a mechanistic link between TLQP21 and the attenuation (via $\mathrm{C} 1 \mathrm{qBP}$ ) or stimulation (via C3aR1) of microglial functions in health and disease. Microglial C3aR1 or C1qBP might therefore be interesting targets for clinical therapies.

\section{References}

Aguilar E, Pineda R, Gaytán F, Sánchez-Garrido MA, Romero M, RomeroRuiz A, Ruiz-Pino F, Tena-Sempere M, Pinilla L (2013) Characterization of the reproductive effects of the Vgf-derived peptide TLQP-21 in female rats: in vivo and in vitro studies. Neuroendocrinology 98:38-50.

Alder J, Thakker-Varia S, Bangasser DA, Kuroiwa M, Plummer MR, Shors TJ, Black IB (2003) Brain-derived neurotrophic factor-induced gene expression reveals novel actions of VGF in hippocampal synaptic plasticity. J Neurosci 23:10800-10808.

Arbibe L, Mira JP, Teusch N, Kline L, Guha M, Mackman N, Godowski PJ, Ulevitch RJ, Knaus UG (2000) Toll-like receptor 2-mediated NF-kappa B activation requires a Rac1-dependent pathway. Nat Immunol 1:533-540.

Bartolomucci A, La Corte G, Possenti R, Locatelli V, Rigamonti AE, Torsello A, Bresciani E, Bulgarelli I, Rizzi R, Pavone F, D’Amato FR, Severini C, Mignogna G, Giorgi A, Schininà ME, Elia G, Brancia C, Ferri GL, Conti R, Ciani B, et al. (2006) TLQP-21, a VGF-derived peptide, increases energy expenditure and prevents the early phase of diet-induced obesity. Proc Natl Acad Sci U S A 103:14584-14589.

Bodea LG, Wang Y, Linnartz-Gerlach B, Kopatz J, Sinkkonen L, Musgrove R, Kaoma T, Muller A, Vallar L, Di Monte DA, Balling R, Neumann H
(2014) Neurodegeneration by activation of the microglial complementphagosome pathway. J Neurosci 34:8546-8556.

Boucsein C, Kettenmann H, Nolte C (2000) Electrophysiological properties of microglial cells in normal and pathologic rat brain slices. Eur J Neurosci 12:2049-2058.

Boucsein C, Zacharias R, Färber K, Pavlovic S, Hanisch UK, Kettenmann H (2003) Purinergic receptors on microglial cells: functional expression in acute brain slices and modulation of microglial activation in vitro. Eur J Neurosci 17:2267-2276.

Butovsky O, Jedrychowski MP, Moore CS, Cialic R, Lanser AJ, Gabriely G, Koeglsperger T, Dake B, Wu PM, Doykan CE, Fanek Z, Liu L, Chen Z, Rothstein JD, Ransohoff RM, Gygi SP, Antel JP, Weiner HL (2014) Identification of a unique TGF-beta-dependent molecular and functional signature in microglia. Nat Neurosci 17:131-143.

Carrette O, Demalte I, Scherl A, Yalkinoglu O, Corthals G, Burkhard P, Hochstrasser DF, Sanchez JC (2003) A panel of cerebrospinal fluid potential biomarkers for the diagnosis of Alzheimer's disease. Proteomics 3:1486-1494.

Chen YC, Pristerá A, Ayub M, Swanwick RS, Karu K, Hamada Y, Rice AS, Okuse K (2013) Identification of a receptor for neuropeptide VGF and its role in neuropathic pain. J Biol Chem 288:34638-34646.

Cocco C, Corda G, Lisci C, Noli B, Carta M, Brancia C, Manca E, Masala C, Marrosu F, Solla P, Manconi B, Bongioanni P, Ferri GL (2020) VGF peptides as novel biomarkers in Parkinson's disease. Cell Tissue Res 379:93-107.

Cox J, Mann M (2008) MaxQuant enables high peptide identification rates, individualized p.p.b.-range mass accuracies and proteome-wide protein quantification. Nat Biotechnol 26:1367-1372.

Davalos D, Grutzendler J, Yang G, Kim JV, Zuo Y, Jung S, Littman DR, Dustin ML, Gan WB (2005) ATP mediates rapid microglial response to local brain injury in vivo. Nat Neurosci 8:752-758.

Dissing-Olesen L, LeDue JM, Rungta RL, Hefendehl JK, Choi HB, MacVicar BA (2014) Activation of neuronal NMDA receptors triggers transient ATP-mediated microglial process outgrowth. J Neurosci 34:1051110527.

Fairbanks CA, Peterson CD, Speltz RH, Riedl MS, Kitto KF, Dykstra JA, Braun PD, Sadahiro M, Salton SR, Vulchanova L (2014) The VGFderived peptide TLQP-21 contributes to inflammatory and nerve injuryinduced hypersensitivity. Pain 155:1229-1237.

Fargali S, Garcia AL, Sadahiro M, Jiang C, Janssen WG, Lin WJ, Cogliani V, Elste A, Mortillo S, Cero C, Veitenheimer B, Graiani G, Pasinetti GM, Mahata SK, Osborn JW, Huntley GW, Phillips GR, Benson DL, Bartolomucci A, Salton SR (2014) The granin VGF promotes genesis of secretory vesicles, and regulates circulating catecholamine levels and blood pressure. FASEB J 28:2120-2133.

Hannedouche S, Beck V, Leighton-Davies J, Beibel M, Roma G, Oakeley EJ, Lannoy V, Bernard J, Hamon J, Barbieri S, Preuss I, Lasbennes MC, Sailer AW, Suply T, Seuwen K, Parker CN, Bassilana F (2013) Identification of the C3a receptor (C3AR1) as the target of the VGF-derived peptide TLQP-21 in rodent cells. J Biol Chem 288:27434-27443.

Haynes SE, Hollopeter G, Yang G, Kurpius D, Dailey ME, Gan WB, Julius D (2006) The P2Y12 receptor regulates microglial activation by extracellular nucleotides. Nat Neurosci 9:1512-1519.

Hendrickson RC, Lee AY, Song Q, Liaw A, Wiener M, Paweletz CP, Seeburger JL, Li J, Meng F, Deyanova EG, Mazur MT, Settlage RE, Zhao X, Southwick K, Du Y, Holder D, Sachs JR, Laterza OF, Dallob A, Chappell DL, et al. (2015) High resolution discovery proteomics reveals candidate disease progression markers of Alzheimer's disease in human cerebrospinal fluid. PLoS One 10:e0135365.

Hickman SE, Kingery ND, Ohsumi TK, Borowsky ML, Wang LC, Means TK, El Khoury J (2013) The microglial sensome revealed by direct RNA sequencing. Nat Neurosci 16:1896-1905.

Jiang C, Lin WJ, Labonté B, Tamminga CA, Turecki G, Nestler EJ, Russo SJ, Salton SR (2019) VGF and its C-terminal peptide TLQP-62 in ventromedial prefrontal cortex regulate depression-related behaviors and the response to ketamine. Neuropsychopharmacology 44:971-981.

Kanashova T, Popp O, Orasche J, Karg E, Harndorf H, Stengel B, Sklorz M, Streibel T, Zimmermann R, Dittmar G (2015) Differential proteomic analysis of mouse macrophages exposed to adsorbate-loaded heavy fuel oil derived combustion particles using an automated sample-preparation workflow. Anal Bioanal Chem 407:5965-5976.

Kettenmann H, Hanisch UK, Noda M, Verkhratsky A (2011) Physiology of microglia. Physiol Rev 91:461-553. 
Klos A, Wende E, Wareham KJ, Monk PN (2013) International union of basic and clinical pharmacology [corrected]. LXXXVII: complement peptide C5a, C4a, and C3a receptors. Pharmacol Rev 65:500-543.

Koizumi S, Shigemoto-Mogami Y, Nasu-Tada K, Shinozaki Y, Ohsawa K, Tsuda M, Joshi BV, Jacobson KA, Kohsaka S, Inoue K (2007) UDP acting at P2Y6 receptors is a mediator of microglial phagocytosis. Nature 446:1091-1095.

Korvers L, de Andrade Costa A, Mersch M, Matyash V, Kettenmann H, Semtner M (2016) Spontaneous $\mathrm{Ca}^{2+}$ transients in mouse microglia. Cell Calcium 60:396-406.

Lewis JE, Brameld JM, Jethwa PH (2015) Neuroendocrine role for VGF. Front Endocrinol (Lausanne) 6:3.

Lin WJ, Jiang C, Sadahiro M, Bozdagi O, Vulchanova L, Alberini CM, Salton SR (2015) VGF and its C-terminal peptide TLQP-62 regulate memory formation in hippocampus via a BDNF-TrkB-dependent mechanism. J Neurosci 35:10343-10356.

Litvinchuk A, Wan YW, Swartzlander DB, Chen F, Cole A, Propson NE, Wang Q, Zhang B, Liu Z, Zheng H (2018) Complement C3aR inactivation attenuates tau pathology and reverses an immune network deregulated in tauopathy models and Alzheimer's disease. Neuron 100: 1337-1353.e5.

Llano DA, Devanarayan P, Devanarayan V (2019) VGF in cerebrospinal fluid combined with conventional biomarkers enhances prediction of conversion from MCI to AD. Alzheimer Dis Assoc Disord 33:307-314.

Madry C, Kyrargyri V, Arancibia-Cárcamo IL, Jolivet R, Kohsaka S, Bryan RM, Attwell D (2018) Microglial ramification, surveillance, and interleukin-1beta release are regulated by the two-pore domain $\mathrm{K}(+)$ channel THIK-1. Neuron 97:299-312.e296.

Molteni L, Rizzi L, Bresciani E, Possenti R, Petrocchi Passeri P, Ghè C, Muccioli G, Fehrentz JA, Verdié P, Martinez J, Omeljaniuk RJ, Biagini G, Binda A, Rivolta I, Locatelli V, Torsello A (2017) Pharmacological and biochemical characterization of TLQP-21 activation of a binding site on CHO cells. Front Pharmacol 8:167.

Nimmerjahn A, Kirchhoff F, Helmchen F (2005) Resting microglial cells are highly dynamic surveillants of brain parenchyma in vivo. Science 308:1314-1318.

Ousingsawat J, Wanitchakool P, Kmit A, Romao AM, Jantarajit W, Schreiber R, Kunzelmann K (2015) Anoctamin 6 mediates effects essential for innate immunity downstream of $\mathrm{P} 2 \mathrm{X} 7$ receptors in macrophages. Nat Commun 6:6245.

Pannell M, Meier MA, Szulzewsky F, Matyash V, Endres M, Kronenberg G, Prinz V, Waiczies S, Wolf SA, Kettenmann H (2016) The subpopulation of microglia expressing functional muscarinic acetylcholine receptors expands in stroke and Alzheimer's disease. Brain Struct Funct 221:1157-1172.

Peerschke EI, Ghebrehiwet B (2007) The contribution of gC1qR/p33 in infection and inflammation. Immunobiology 212:333-342.

Pinilla L, Pineda R, Gaytán F, Romero M, García-Galiano D, SánchezGarrido MA, Ruiz-Pino F, Tena-Sempere M, Aguilar E (2011) Characterization of the reproductive effects of the anorexigenic VGF-derived peptide TLQP-21: in vivo and in vitro studies in male rats. Am J Physiol Endocrinol Metab 300:E837-E847.

Possenti R, Muccioli G, Petrocchi P, Cero C, Cabassi A, Vulchanova L, Riedl MS, Manieri M, Frontini A, Giordano A, Cinti S, Govoni P, Graiani G, Quaini F, Ghe C, Bresciani E, Bulgarelli I, Torsello A, Locatelli V, Sanghez $\mathrm{V}$, et al. (2012) Characterization of a novel peripheral pro-lipolytic mechanism in mice: role of VGF-derived peptide TLQP-21. Biochem J 441:511-522.

Rappsilber J, Mann M, Ishihama Y (2007) Protocol for micro-purification, enrichment, pre-fractionation and storage of peptides for proteomics using StageTips. Nat Protoc 2:1896-1906.

Rizzi R, Bartolomucci A, Moles A, D’Amato F, Sacerdote P, Levi A, La Corte G, Ciotti MT, Possenti R, Pavone F (2008) The VGF-derived peptide TLQP-21: a new modulatory peptide for inflammatory pain. Neurosci Lett 441:129-133.

Sakamoto M, Miyazaki Y, Kitajo K, Yamaguchi A (2015) VGF, which is induced transcriptionally in stroke brain, enhances neurite extension and confers protection against ischemia in vitro. Transl Stroke Res 6:301-308.
Sarkar SN, Peters KL, Elco CP, Sakamoto S, Pal S, Sen GC (2004) Novel roles of TLR3 tyrosine phosphorylation and PI3 kinase in double-stranded RNA signaling. Nat Struct Mol Biol 11:1060-1067.

Sasmono RT, Oceandy D, Pollard JW, Tong W, Pavli P, Wainwright BJ, Ostrowski MC, Himes SR, Hume DA (2003) A macrophage colonystimulating factor receptor-green fluorescent protein transgene is expressed throughout the mononuclear phagocyte system of the mouse. Blood 101:1155-1163.

Sasmono RT, Williams E (2012) Generation and characterization of MacGreen mice, the Cfs1r-EGFP transgenic mice. Methods Mol Biol 844:157-176.

Sato H, Fukutani Y, Yamamoto Y, Tatara E, Takemoto M, Shimamura K, Yamamoto N (2012) Thalamus-derived molecules promote survival and dendritic growth of developing cortical neurons. J Neurosci 32: $15388-15402$.

Severini C, Ciotti MT, Biondini L, Quaresima S, Rinaldi AM, Levi A, Frank C, Possenti R (2008) TLQP-21, a neuroendocrine VGF-derived peptide, prevents cerebellar granule cells death induced by serum and potassium deprivation. J Neurochem 104:534-544.

Severini C, La Corte G, Improta G, Broccardo M, Agostini S, Petrella C, Sibilia V, Pagani F, Guidobono F, Bulgarelli I, Ferri GL, Brancia C, Rinaldi AM, Levi A, Possenti R (2009) In vitro and in vivo pharmacological role of TLQP-21, a VGF-derived peptide, in the regulation of rat gastric motor functions. Br J Pharmacol 157:984-993.

Sharma K, Schmitt S, Bergner CG, Tyanova S, Kannaiyan N, ManriqueHoyos N, Kongi K, Cantuti L, Hanisch UK, Philips MA, Rossner MJ, Mann M, Simons M (2015) Cell type- and brain region-resolved mouse brain proteome. Nat Neurosci 18:1819-1831.

Shevchenko A, Tomas H, Havlis J, Olsen JV, Mann M (2006) In-gel digestion for mass spectrometric characterization of proteins and proteomes. Nat Protoc 1:2856-2860.

Spellman DS, Wildsmith KR, Honigberg LA, Tuefferd M, Baker D, Raghavan N, Nairn AC, Croteau P, Schirm M, Allard R, Lamontagne J, Chelsky D, Hoffmann S, Potter WZ (2015) Development and evaluation of a multiplexed mass spectrometry based assay for measuring candidate peptide biomarkers in Alzheimer's disease neuroimaging initiative (ADNI) CSF. Proteomics Clin Appl 9:715-731.

Surugiu R, Catalin B, Dumbrava D, Gresita A, Olaru DG, Hermann DM, Popa-Wagner A (2019) Intracortical administration of the complement C3 receptor antagonist trifluoroacetate modulates microglia reaction after brain injury. Neural Plast 2019:1071036.

Tabula Muris Consortium (2018) Single-cell transcriptomics of 20 mouse organs creates a Tabula Muris. Nature 562:367-372.

van Steenoven I, Noli B, Cocco C, Ferri GL, Oeckl P, Otto M, Koel-Simmelink MJA, Bridel C, van der Flier WM, Lemstra AW, Teunissen CE (2019) VGF peptides in cerebrospinal fluid of patients with dementia with Lewy bodies. Int J Mol Sci 20:E4674.

Wendt S, Maricos M, Vana N, Meyer N, Guneykaya D, Semtner M, Kettenmann $H$ (2017) Changes in phagocytosis and potassium channel activity in microglia of $5 \mathrm{xFAD}$ mice indicate alterations in purinergic signaling in a mouse model of Alzheimer's disease. Neurobiol Aging 58:41-53.

Wiggins HL, Rappoport JZ (2010) An agarose spot assay for chemotactic invasion. Biotechniques 48:121-124.

Wolf SA, Boddeke HW, Kettenmann H (2017) Microglia in physiology and disease. Annu Rev Physiol 79:619-643.

Xu Y, Hu W, Liu Y, Xu P, Li Z, Wu R, Shi X, Tang Y (2016) P2Y6 receptormediated microglial phagocytosis in radiation-induced brain injury. Mol Neurobiol 53:3552-3564.

Zhang Y, Chen K, Sloan SA, Bennett ML, Scholze AR, O'Keeffe S, Phatnani HP, Guarnieri P, Caneda C, Ruderisch N, Deng S, Liddelow SA, Zhang C, Daneman R, Maniatis T, Barres BA, Wu JQ (2014) An RNA-sequencing transcriptome and splicing database of glia, neurons, and vascular cells of the cerebral cortex. J Neurosci 34:11929-11947.

Zhao X, Liao Y, Morgan S, Mathur R, Feustel P, Mazurkiewicz J, Qian J, Chang J, Mathern GW, Adamo MA, Ritaccio AL, Gruenthal M, Zhu X, Huang Y (2018) Noninflammatory changes of microglia are sufficient to cause epilepsy. Cell Rep 22:2080-2093. 